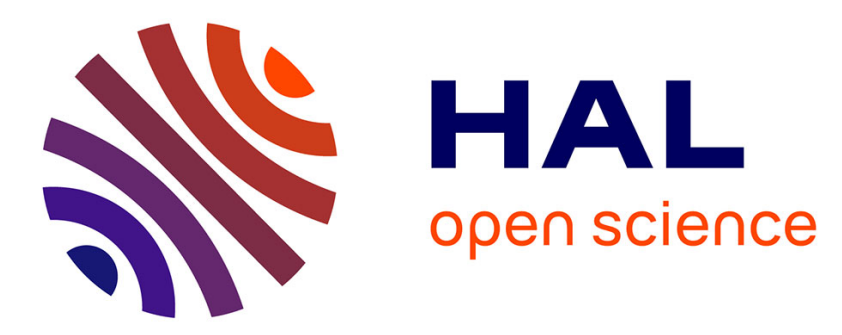

\title{
Calmodulin-independent, agonistic properties of a peptide containing the calmodulin binding site of estrogen receptor $\alpha$
}

Dominique Gallo, Françoise Jacquemotte, Anny Cleeren, Ioanna Laïos, Samira Hadiy, Martin G. Rowlands, Olivier Caille, Denis Nonclercq, Guy Laurent, Yves Jacquot, et al.

\section{To cite this version:}

Dominique Gallo, Françoise Jacquemotte, Anny Cleeren, Ioanna Laïos, Samira Hadiy, et al.. Calmodulin-independent, agonistic properties of a peptide containing the calmodulin binding site of estrogen receptor $\alpha$. Molecular and Cellular Endocrinology, 2007, 268 (1-2), pp.37. 10.1016/j.mce.2007.01.012 . hal-00531912

\section{HAL Id: hal-00531912 https://hal.science/hal-00531912}

Submitted on 4 Nov 2010

HAL is a multi-disciplinary open access archive for the deposit and dissemination of scientific research documents, whether they are published or not. The documents may come from teaching and research institutions in France or abroad, or from public or private research centers.
L'archive ouverte pluridisciplinaire HAL, est destinée au dépôt et à la diffusion de documents scientifiques de niveau recherche, publiés ou non, émanant des établissements d'enseignement et de recherche français ou étrangers, des laboratoires publics ou privés. 


\section{Accepted Manuscript}

Title: Calmodulin-independent, agonistic properties of a peptide containing the calmodulin binding site of estrogen receptor $\alpha$

Authors: Dominique Gallo, Françoise Jacquemotte, Anny Cleeren, Ioanna Laïos, Samira Hadiy, Martin G. Rowlands,

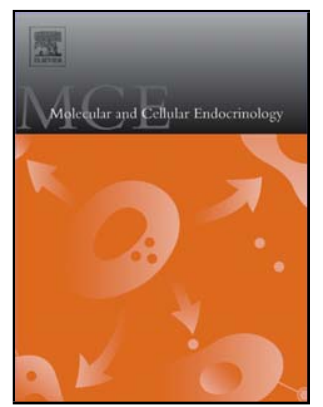
Olivier Caille, Denis Nonclercq, Guy Laurent, Yves Jacquot, Guy Leclercq

PII: S0303-7207(07)00032-9

DOI: doi:10.1016/j.mce.2007.01.012

Reference: MCE 6598

To appear in: $\quad$ Molecular and Cellular Endocrinology

Received date: 6-10-2006

Revised date: $\quad 15-1-2007$

Accepted date: $\quad 18-1-2007$

Please cite this article as: Gallo, D., Jacquemotte, F., Cleeren, A., Laïos, I., Hadiy, S., Rowlands, M.G., Caille, O., Nonclercq, D., Laurent, G., Jacquot, Y., Leclercq, G., Calmodulin-independent, agonistic properties of a peptide containing the calmodulin binding site of estrogen receptor $\alpha$, Molecular and Cellular Endocrinology (2007), doi:10.1016/j.mce.2007.01.012

This is a PDF file of an unedited manuscript that has been accepted for publication. As a service to our customers we are providing this early version of the manuscript. The manuscript will undergo copyediting, typesetting, and review of the resulting proof before it is published in its final form. Please note that during the production process errors may be discovered which could affect the content, and all legal disclaimers that apply to the journal pertain. 
Calmodulin-independent, agonistic properties of a peptide containing the calmodulin binding site of estrogen receptor $\alpha$

\title{
Running title : Regulatory properties of P295-T311 sequence of ER $\alpha$
}

Dominique Gallo ${ }^{a}$, Françoise Jacquemotte ${ }^{b}$, Anny Cleeren ${ }^{a}$, loanna Laïos ${ }^{a}$, Samira Hadiy $^{\mathrm{a}}$, Martin G. Rowlands ${ }^{\mathrm{c}}$, Olivier Caille ${ }^{\mathrm{d}}$, Denis Nonclercq ${ }^{\mathrm{e}}$, Guy Laurent ${ }^{\mathrm{e}}$, Yves Jacquot ${ }^{f}$ and Guy Leclercq ${ }^{\mathrm{a},}$

a Laboratoire J.-C. Heuson de Cancérologie Mammaire, Université Libre de Bruxelles, Institut Jules Bordet, 1 rue Héger-Bordet, B-1000 Brussels, Belgium

${ }^{b}$ Département des Substances Naturelles et de Biochimie, Institut Meurice, 1 avenue Emile Gryzon, B-1070 Brussels, Belgium

${ }^{\mathrm{C}}$ Cancer Research Campaign Center for Cancer Therapeutics, Haddow Laboratories, Institute of Cancer Research, Cotswold Road, Sutton, Surrey, SM2 5 NG UK

${ }^{\mathrm{d}}$ Laboratoire de Biologie Moléculaire des Plantes Supérieures (LBMPS), Université de Genève, 30 Quai Ernest Ansermet, 1211 Geneva 4, Switzerland.

${ }^{e}$ Service d'Histologie et de Cytologie Expérimentale, Faculté de Médecine et de Pharmacie, Université de Mons-Hainaut, 6 avenue du Champ de Mars, B-7000 Mons, Belgium

f Université Pierre et Marie Curie-Paris 6, UMR 7613; CNRS, UMR 7613, "Synthèse, Structure et Fonction de Molécules Bioactives"; FR 2769, UMR 7613; Case courrier 45, 4 place Jussieu, 75005 Paris, France

\author{
* Corresponding author : \\ Prof. Guy Leclercq \\ Laboratoire J.-C. Heuson de Cancérologie Mammaire \\ Institut Jules Bordet \\ 1 rue Héger-Bordet \\ B-1000 Brussels \\ Belgium \\ Phone: +3225413744 , Fax: +3225413498 \\ e-mail: Icanmamm@ulb.ac.be
}

Key words: Estrogen receptor $\alpha$, Calmodulin, Peptide, Breast cancer 


\section{ABSTRACT}

Calmodulin (CaM) contributes to estrogen receptor $\alpha(E R)$-mediated transcription. In order to study the underlying mechanisms, we synthesized a peptide including the CaM binding site : ER $\alpha 17 p\left(P_{295}-T_{311}\right)$. This peptide inhibited ER-CaM association, unlike two analogs in which two amino acids required for CaM binding were substituted. Exposure of MCF-7 cells to ER $\alpha 17 p$ down regulated $E R$, stimulated ERdependent transcription and enhanced the proliferation of ER-positive breast cancer cell lines. Interestingly, ER $\alpha 17 p$ analogs unable to bind to CaM induced similar responses, demonstrating that $\mathrm{ER} \alpha 17 \mathrm{p}$-mediated effects are mainly relevant to mechanisms independent of ER-CaM dissociation. The $P_{295}-T_{311}$ motif is indeed a platform for multiple post-translational modifications not necessarily CaM-dependent. The additional finding that deletion of the $P_{295}-T_{311}$ sequence in $E R$ produced a constitutive transcriptional activity revealed that this platform motif has autorepressive functions. With regard to cell function, association of CaM to ER would counteract this autorepression, leading thereby to enhanced ER-mediated transactivation. 


\section{INTRODUCTION}

Implication of estrogens and their receptors in growth, differentiation and function of a variety of target tissues is now well established. Two estrogen receptor isoforms ( $\alpha$ and $\beta$ ) have been identified, estrogen receptor $\alpha$ (hereinafter referred to as ER) is the dominant isoform expressed in breast cancer. Studies of our laboratory are devoted to the analysis of the mechanisms by which this receptor contributes to the pathogenesis of breast tumors. ER belongs to the superfamily of nuclear receptors which are known to act as ligand-dependent transcription factors (Evans, 1988; Leclercq et al., 2006). Actually, ER biological activities are modulated by formation of diverse transient complexes with a variety of co-regulators (Rossini, 1994). Calmodulin (CaM), an ubiquitous $\mathrm{Ca}^{++}$sensor protein, is one of these co-regulators, the importance of which in ER-mediated transcription is now well recognized (Biswas et al., 1998; Garcia Pedrero et al., 2002; Li et al., 2003; Li et al., 2005).

Early studies revealed that the association of CaM with ER enhances the binding of the latter to estrogen response elements (ERE) (Biswas et al., 1998; Bouhoute and Leclercq, 1995), a step of prime importance for initiating the transcription of estrogenregulated genes. There is indeed a general consensus that transcription occurs according to a well defined cyclic process involving the combinatorial and sequential recruitment of enzymes and factors required for the assembly of transcriptionally productive complexes (Reid et al., 2003; Metivier et al., 2003; Shang et al., 2000). In each cycle, proteasomal degradation of ER molecules that have fulfilled their role in initiation has to occur since the promoters of target genes must be free for the assembly of new complexes. This elimination process facilitates the access of newly 
synthesized receptors to the promoters, in order to initiate subsequent transcriptional cycles required for maintaining high gene expression. Hence, mechanisms that govern transcription and turnover rate of ER are closely interrelated (Reid et al., 2003; Metivier et al., 2003; Yan et al., 2003; Laios et al., 2005). Unexpectedly CaM, while being an important determinant of ER-mediated transcription (Biswas et al., 1998; Garcia Pedrero et al., 2002; Li et al., 2003; Li et al., 2005) has been reported to protect ER against proteasomal degradation (Castoria et al., 1988; Li et al., 2001; Li et al., 2006). This paradox led us to explore further the mechanism of action of this co-regulator.

Current studies aimed at analyzing the mechanism of action of nuclear receptors and their co-regulators often concentrate on the identification of small amino acid sequences putatively involved in specific protein-protein interactions. In this regard, synthetic peptides including such sequences are valuable tools for studying the biological significance of receptor - co-regulator interactions, as well as for the development of selective antagonists (Xu et al., 2002; lannone et al., 2004; Rodriguez et al., 2004; Shao et al., 2004). It seemed therefore to us that a peptide corresponding to the CaM binding site in ER would prove to be useful for understanding the mechanism by which $\mathrm{CaM}$ cooperates with the receptor in the regulation of gene expression. The present paper describes the biological properties of a 17 amino acids synthetic peptide (ER $\alpha 17 p$; Fig. 1C) containing an ER motif known to be involved in CaM binding (Garcia Pedrero et al., 2002; Li et al., 2005; Castoria et al., 1988). 


\section{MATERIAL AND METHODS}

\section{Chemicals}

Calmodulin-Sepharose $4 \mathrm{~B}$ and $\left[2,4,6,7-{ }^{3} \mathrm{H}\right]$ estradiol $\left(\left[{ }^{3} \mathrm{H}\right] \mathrm{E}_{2} ; \sim 100 \mathrm{Ci} / \mathrm{mmol}\right)$ were purchased from Amersham Biosciences (Buckinghamshire, U.K.). Highly purified human recombinant ER (hER) and MG-132 were obtained from Calbiochem (San Diego, CA). Estradiol $\left(\mathrm{E}_{2}\right)$, calmidazolium chloride, N-(6-Aminohexyl)-5-chloro-1naphthalenesulfonamide hydrochloride (W-7), ophiobolin A, dansylated CaM, and phenylmethylsulfonyl fluoride (PMSF) were from Sigma (St Louis, MO). TosylLphenylalaninechloromethylketone (TPCK) came from Roche Diagnostics (Mannheim, Germany).

\section{Antibodies}

Anti-ER antibodies - i.e. D-12 (mouse monoclonal) and H-184 (rabbit polyclonal) raised against amino acids 2-185 mapping within the A/B domain, G-20 (rabbit polyclonal) raised against residues 281-300 within the D domain, F-10 (mouse monoclonal) and HC-20 (rabbit polyclonal) raised against residues 576-595 within the F domain - were obtained from Santa Cruz Biotechnology (Santa Cruz, CA). AER308 (mouse monoclonal) raised against the D/E boundary (residues 283-339) was from Abcam (Cambridge, UK).

Anti-CaM mouse monoclonal antibody was purchased from Upstate (Lake Placid, NY). MAB1501R mouse monoclonal anti-actin was from Chemicon (Temecula, CA). Peroxidase-labeled secondary antibody was from Pierce (Rockford, IL) and antirabbit IgG agarose from Sigma. 


\section{Peptides}

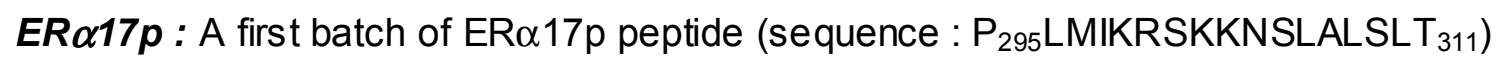
was gratefully produced by UCB-Bioproducts (Brussels, Belgium) for preliminary studies. The second preparation was synthesized in the Natural Substances laboratory of Meurice Institute (Brussels, Belgium) by the Atherton and Sheppard solid phase peptide synthesis method (Atherton and Sheppard, 1989) on an Advanced ChemTech 90 apparatus. Briefly, 0.25 mM of Fmoc-Thr(But)-Wang resin ( $0.5 \mathrm{mM} / \mathrm{g}$ ) was used as solid support. Fmoc-Leu-OPfp, Fmoc-Ser(OBut)-Dhbt, FmocLeu-OPfp, Fmoc-Ala-OPfp, Fmoc-Leu-OPfp, Fmoc-Ser(OBut)-Dhbt, Fmoc-Asn(Trt)OH, Fmoc-Lys(Boc)-OPfp, Fmoc-Lys(Boc)-OPfp, Fmoc-Ser(OBut)-Dhbt, Fmoc$\operatorname{Arg}(\mathrm{Pmc})-\mathrm{OH}$, Fmoc-Lys(Boc)-OPfp, Fmoc-lle-OH, Fmoc-Met-Dhbt, Fmoc-Leu-OPfp and Fmoc-Pro-OPfp (0.75 mM) were successively coupled in anhydrous DMF (45 min for Dhbt and OPfp, under $\mathrm{N}_{2}$ ) after Fmoc cleavage (20\% piperidine in DMF). Couplings were carried out in the presence of HOBt $(0.75 \mathrm{mM})$ for OPfp esters. Activation method with HBTU $(0.75 \mathrm{mM}, 10 \mathrm{~min})$ (Knorr et al., 1989) was used for Fmoc amino acids under free form in the presence of DIPEA (1.5 mM). All couplings were controlled step by step by analytical Kaiser test (Kaiser et al., 1970). Final cleavage of Wang resin and protecting groups was achieved with a solution of TFA in the presence of scavengers (TFA / $\mathrm{H}_{2} \mathrm{O} /$ ethanedithiol / TIS ; $94 / 2.5 / 2.5 / 1.0 \mathrm{v} / \mathrm{v}$, 4 hours, under $\mathrm{N}_{2}$ ). ER $\alpha 17 \mathrm{p}$ was then extracted after res in filtration and lyophilized.

ER $\alpha 17 p$ analogs : ER $\alpha 17 p A A$ (sequence : $P_{295} L_{M I K R S A}{ }_{302} A_{303} N_{S L A L S L T}{ }_{311}$ ) and ER $\alpha 17 p G G$ (sequence : $P_{295} L_{M I K R S G}{ }_{302} \mathbf{G}_{303}$ NSLALSLT $_{311}$ ) were synthesized 
according to the same procedure using Fmoc-Ala-OPfp or Fmoc-Gly-OPfp respectively.

Molecular weights and sequences of peptides were gratefully confirmed by the University of Ghent, Belgium (J. Van Beeumen and B. Devreese) by MALDI-TOF and / or MALDI-TOF-TOF mass spectrometry. Purity was checked by analytical RP-HPLC achieved on a Waters HPLC system (Waters 600 Pump and Controller, Waters 2487 Dual $\lambda$ Detector, Waters 746 Data Module) using a $C_{8}$ RP-HPLC column $(4.6 \mathrm{~mm} x$ $300 \mathrm{~mm}, 5 \mu \mathrm{m}$ particle size, $300 \AA$ pore size). Mobile phases consisted of appropriate mixtures of $B\left(60 \%\right.$ acetonitrile : $40 \% \mathrm{H}_{2} \mathrm{O}: 0.1 \%$ TFA v/v $)$ and $\mathrm{A}\left(\mathrm{H}_{2} \mathrm{O}: 0.1 \%\right.$ TFA $\mathrm{v} / \mathrm{v})$

CaM kinase II peptide : This peptide, used as a positive control for CaM binding and CaM-dependent kinase II activity measurement (sequence : L290KKFNARRKLKGAILTTMLA ${ }_{309}$ ), was obtained from Calbiochem/Novabiochem (Nottingham, UK).

\section{Plasmids}

pcDNA3-ERwt : HEO ER $\alpha$ cDNA (1,8 kp fragment EcoRI from vector pSG5-HEO) provided by P. Chambon (Illkirch, France) (Green et al., 1986) was cloned downstream of the CMV promoter into the EcoRI site of pcDNA3 vector (Invitrogen ; Carlsbad, CA).

pcDNA3-ERAER $\alpha 17 p$ : This construction was obtained from pcDNA3-ERwt by deleting the region coding for the amino acid sequence $P_{295}-T_{311}$. PCR, used for that purpose (Imai et al., 1991), was performed using Expand Long Template PCR 
System (Roche Applied Science) with C-terminal 5' - gcttggccaaaggttggcagc - 3' and $\mathrm{N}$-terminal 5' - gccgaccagatggtcagtgcc - 3' primers. PCR product was purified using Wizard SV Gel and PCR Clean-Up System (Promega) and self-ligated (Imai et al., 1991) after blunt-ending with Klenow fragment.

Vit-tk-Luc : Original plasmids tkLuc(puc18-) containing the tk promoter (thymidine kinase) and pVit-tk-Luc containing the regulatory region from $-331 \mathrm{nt}$ to $-86 \mathrm{nt}$ of Xenopus vitellogenin A2 gene (Vit) were both provided by M. Pons (Montpellier, France). The plasmid used in the current study was constructed by cloning the BamHI-HindIII 174 bp fragment containing the tk promoter into the Bglll-HindIII sites of pGL3-Basic (containing the firefly luciferase gene ; Promega). Subsequently, the Bglll-HindIII 476 bp containing the Vit regulatory region was cloned in Bglll-HindIII sites upstream the luciferase gene. Construction was verified by sequencing.

pRL-tk : Plasmid containing the Renilla luciferase gene under the control of the tk promoter was purchased from Promega.

\section{Cell culture}

MCF-7, T47D, IBEP-1, IBEP-3, BT-20, MDA-MB-231, MDA-MB-453, Evsa-T, HS578T, SKBR-3 and MVLN cell lines (from our cancer cell line bank) were maintained in a cell incubator at $37{ }^{\circ} \mathrm{C}$ in humid atmosphere at $5 \% \mathrm{CO}_{2}$, and propagated in Earle's based minimal essential medium (EMEM) supplemented with Phenol Red, 2 $\mathrm{mM}$ L-glutamine, $100 \mathrm{U} / \mathrm{ml}$ penicillin,100 $\mu \mathrm{g} / \mathrm{ml}$ streptomycin and $10 \%$ heatinactivated FBS (all reagents from Invitrogen/Gibco). Experiments were performed in EMEM without Phenol Red and containing $10 \%$ charcoal-stripped FBS in order to 
avoid any potential estrogenic interference. The change of medium was performed 48 hours before treatment, except for growth measurement and transient transfections (24 hours).

\section{CaM-Sepharose binding assays}

CaM-Sepharose 4B was equilibrated beforehand in $10 \mathrm{mM}$ Tris- $\mathrm{HCl} \mathrm{pH} 7.5$ containing $100 \mathrm{mM} \mathrm{KCl}$ and $1 \mu \mathrm{M} \mathrm{CaCl}_{2}$.

ER binding : hER ( 2.5 pmol in $1 \mathrm{ml}$ of equilibration buffer containing $1 \mathrm{mg} / \mathrm{ml} \mathrm{BSA})$ was labeled with $1 \mathrm{nM}\left[{ }^{3} \mathrm{H}\right] \mathrm{E}_{2}$ alone (total binding), or in the presence of a 200 fold excess of $E_{2}$ (non-specific binding). Labeled $\left.{ }^{3} \mathrm{H}\right] \mathrm{E}_{2}-\mathrm{ER}$ complex was incubated overnight with $50 \mu \mathrm{l}$ of CaM-Sepharose suspension (50\% slurry), in presence or absence of anti-ER antibodies $(100 \mathrm{ng} / \mathrm{ml})$, CaM antagonists $(10 \mu \mathrm{M})$ or investigated peptides $(10 \mu \mathrm{M})$. CaM-Sepharose was then washed 3 times with $1 \mu \mathrm{M} \mathrm{Ca}{ }^{2+}$ (fractions 1 to 3 ) and eluted with $10 \mathrm{mM}$ EDTA (fractions 4 to 6 ). ER concentration was determined by measuring radioactivity $\left(\left[{ }^{3} \mathrm{H}\right] \mathrm{E}_{2}\right.$ labeled samples) using a Wallac 1409 liquid scintillation counter (Perkin Elmer ; Boston, MA) or by Western blotting using F-10 anti-ER antibody (see below).

Peptide binding : ER $\alpha 17 p$ and its analogs, dissolved in the equilibration buffer (10 $\mu \mathrm{M} ; 100 \mu \mathrm{l})$ were incubated with CaM-Sepharose or with Sepharose 4B (control for assessment of potential non-specific binding) (50 $\mu \mathrm{l}, 50 \%$ slurry ; 2 hours, $\left.4{ }^{\circ} \mathrm{C}\right)$. After removing unbound peptides (supernatant) matrixes were washed 2 times with 1 $\mu \mathrm{M} \mathrm{Ca}^{2+}$ and bound peptides were eluted with $10 \mathrm{mM}$ EDTA. Twenty $\mu$ l of unbound 
and bound peptide were then separated on a $16.5 \%$ Tris-Tricin gel and revealed by Sypro Ruby staining (Bio-Rad ; Hercules, CA).

\section{Dansylated CaM fluorescence assay}

Direct interaction of ER $\alpha 17 \mathrm{p}$ with $\mathrm{CaM}$ was assessed using dansylated CaM (dansylCaM) in a fluorescence assay (Kincaid et al., 1982). The CaM kinase II peptide was used as positive control. Samples were prepared in quartz cuvettes in a final volume of $3 \mathrm{ml}$ of $10 \mathrm{mM}$ Tris- $\mathrm{HCl}, \mathrm{pH} 7.5,0.1 \mathrm{mM} \mathrm{CaCl}, 150 \mathrm{mM} \mathrm{NaCl}$. Fluorescence measurements were recorded on a Perkin Elmer LS-5B luminescence spectrometer at room temperature with both emission and excitation slits at $5 \mathrm{~nm}$. The excitation wavelength was $340 \mathrm{~nm}$ and the mixture was scanned over an emission wavelength range of $400-600 \mathrm{~nm}$. Specificity of the fluorescence signal was demonstrated by its abrogation in the presence of $500 \mu \mathrm{M}$ EGTA.

\section{Assay of CaM-dependent cAMP phosphodiesterase activity}

The assay of cAMP phosphodiesterase activity was performed with $\left[8-{ }^{3} \mathrm{H}\right] \mathrm{cAMP}$ (Amersham Biosciences) as substrate, under optimal conditions i.e. $100 \mu \mathrm{M}$ [8$\left.{ }^{3} \mathrm{H}\right] \mathrm{CAMP}(0.1 \mu \mathrm{Ci}), 100 \mathrm{ng}(3.6 \mathrm{U}) \mathrm{CaM}, 2 \mathrm{mU}$ of beef heart phosphodiesterase (EC. 3.1.4.17) in $40 \mathrm{mM}$ Tris- $\mathrm{HCl} \mathrm{pH} 7.4,4 \mathrm{mM}$ DTT, $5 \mathrm{mM} \mathrm{MgCl}$. Basal activity (CaM independent) was determined by adding $1 \mathrm{mM} \mathrm{EGTA}$ to the medium. Tritiated AMP formed during the incubation was converted into tritiated adenosine by 5'nucleotidase from snake venom. Nucleoside products were separated from unreacted substrate by batch elution with Dowex anion exchange resin and tritiated 
adenosine level determined by liquid scintillation counting (Rowlands et al., 1990; McCague et al., 1994).

\section{MTT cytotoxicity assay}

MCF-7 cells were seeded in 96-well plates (3000 cells/well). After treatment $(6,16$, 24 or 48 hours) with CaM antagonists (calmidazolium chloride, W-7 or ophiobolin A) or ER $\alpha 17 p$, cell viability was assayed by exposure to $0.03 \% \mathrm{MTT}$ dissolved in EMEM without Phenol Red (90 min, $\left.37^{\circ} \mathrm{C}\right)$. After medium removal, produced formazan was dissolved in DMSO (1 hour, room temperature, under agitation) for measurement by spectrometry at 550 nm using a Microplate Autoreader EL309 (BIOTEK Instruments ; Winooski, VT).

\section{Co-immunoprecipitation}

MCF-7 cells were incubated for 2 hours with CaM antagonists or with ER $\alpha 17 p$ in serum free condition. They were then washed with PBS (40 mM Na $2 \mathrm{HPO}_{4}, 10 \mathrm{mM}$ $\mathrm{KH}_{2} \mathrm{PO}_{4}, 120 \mathrm{mM} \mathrm{NaCl}, \mathrm{pH}$ 7.2) and lysed in TBS (50 mM Tris- $\mathrm{HCl}, 150 \mathrm{mM} \mathrm{NaCl}$, $\mathrm{pH} 7.5)$ containing $0.5 \% \mathrm{NP}-40,0.2 \mathrm{mM} \mathrm{Ca}^{2+}, 0.6 \mathrm{mM}$ PMSF and $0.3 \mathrm{mM}$ TPCK. Lysates were clarified by centrifugation and immunoprecipitated (Laios et al., 2005). Briefly, for each sample, cell lysates corresponding to $250 \mu \mathrm{g}$ of total protein were pre-cleared using agarose-coupled anti-rabbit IgG (45 $\mu$ l, $50 \%$ slurry, 2 hours, $\left.4{ }^{\circ} \mathrm{C}\right)$ and were thereafter incubated with IgG anti-ER antibody (HC-20;2 $\mu \mathrm{g}$, overnight, 4 $\left.{ }^{\circ} \mathrm{C}\right)$. ER-antibody complexes were precipitated by agarose-coupled anti-rabbit IgG (45 $\mu$ l, $50 \%$ slurry, 2 hours, $4{ }^{\circ} \mathrm{C}$ ). After washing, pellets, were suspended in $60 \mu \mathrm{l}$ 
electrophoresis buffer (LDS Sample $1 \mathrm{X}$ buffer ; Invitrogen) and boiled for $5 \mathrm{~min}$. ER and associated CaM levels were measured by Western blot analysis (see below).

\section{ER measurement (whole cell $\left[{ }^{3} \mathrm{H}\right] \mathrm{E}_{2}$ binding assay)}

In order to determine ER binding capacity, MCF-7 cells were plated in 24-well dishes. Two days later, cells were exposed for 24 hours to increasing amounts of ER $\alpha 17 \mathrm{p}$ (1 to $50 \mu \mathrm{M})$. Medium was then removed and exposed to $1 \mathrm{nM}$ of $\left[{ }^{3} \mathrm{H}\right] \mathrm{E}_{2}$ in serum-free EMEM without Phenol Red. Additional wells were filled with a 500-fold excess of unlabelled $E_{2}$ for non-specific binding (NSB) measurement. After 45 min of incubation, the medium was again removed and the monolayer washed three times with PBS. Cell-bound radioactivity was finally extracted with ethanol (30 min, room temperature) and measured by scintillation counting.

For binding kinetics analysis, a similar protocol was used, except that MCF-7 cells were incubated for different periods of time ( $6 \mathrm{~h}$ to $48 \mathrm{~h}$, see Results) in presence of ER $\alpha 17 p$ or ER $\alpha 17 p$ analogs at $10 \mu \mathrm{M}$, without or with $1 \mu \mathrm{M}$ MG-132. Thereafter, cells were exposed to $\left[{ }^{3} \mathrm{H}\right] \mathrm{E}_{2}$ at several concentrations (from 0.05 to $1 \mathrm{nM}$ ) without or with excess of unlabelled $E_{2}$; two additional wells were used for assessing protein concentration in cell extracts. Binding kinetics parameters (i.e. dis sociation constant $K d$ and binding capacity Bmax) were determined by Scatchard plot analysis (Scatchard, 1949).

\section{Western blot analysis}


After treatment with CaM antagonists, $E_{2}$, ER $\alpha 17 p$ or ER $\alpha 17 p$ analogs, MCF-7 cells were washed with PBS before lysis in TBS containing $1 \%$ NP-40, $0.1 \%$ SDS, $0.5 \%$ sodium deoxycholate, $50 \mathrm{mM} \mathrm{NaF}, 0.1 \mathrm{mM}$ orthovanadate, $0.6 \mathrm{mM}$ PMSF and 0.3 mM TPCK. Lysates were clarified and protein concentration of each sample was determined by BCA protein assay kit (Pierce). After addition of LDS Sample 4X buffer (Invitrogen), samples were boiled for 5 minutes and submitted (15 $\mu \mathrm{g}$ protein per lane) to electrophoresis on 4-12 \% SDS-PAGE gel (Invitrogen). Separated proteins were electrotransferred onto Hybond ECL nitrocellulose membrane (Amersham) using a semi-dry blotting apparatus (Bio-Rad). Non-specific sites were blocked by pretreatment with $5 \%$ non-fat dry milk in TBS containing $0.05 \%$ Tween 20 (2 hours, room temperature). Membranes were then incubated overnight at $4^{\circ} \mathrm{C}$ with anti-ER (D-12 or F-10), anti-CaM or anti-actin (MAB1501R) antibodies (dilutions of $1: 1000,1$ : 3000, $1: 1000$ and $1: 7500$ respectively). Detection was performed by chemiluminescence, using a peroxidase-coupled secondary antibody (dilution of 1 : 2000, 1.5 hours, room temperature) and Western Pico Detection system (Pierce). Immunoblots were visualized using FLA-3000 camera (Fuji ; Tokyo, Japan). Densitometric analyses were performed using Aida software.

\section{ER immunofluorescence staining}

MCF-7 cells were plated on sterile round glass coverslips in 12-well dishes. Two days after seeding, cells were incubated with ER $\alpha 17 \mathrm{p}$ at $10 \mu \mathrm{M}$. After 24 hours exposure, cell monolayers were rinsed with Dulbecco's PBS (DPBS) and fixed at $4{ }^{\circ} \mathrm{C}$ with phosphate-buffered $4 \%$ paraformaldehyde (PAF). Following fixation, PAF was 
changed for DPBS. Demonstration of ER by immunofluorescence was achieved as described previously (Brohee et al., 2000). In short, cell monolayers were rinsed several times with PBS containing $0.1 \%$ Triton $\mathrm{X}-100$. Before exposure to the primary antibody, cells were preincubated for $20 \mathrm{~min}$ in PBS containing $0.05 \%$ casein (PBS-cas ; Sigma) and $50 \mathrm{mM} \mathrm{NH}_{4} \mathrm{Cl}$ to prevent non-specific adsorption of immunoglobulins. Cells were then exposed for 1 hour to $\mathrm{HC}-20$ antibody diluted 1 : 50 in PBS-cas. Thereafter, they were incubated for $30 \mathrm{~min}$ in the presence of a dextran polymer conjugated with both peroxidase and antibodies raised against rabbit immunoglobulins (EnVision ${ }^{\mathrm{TM}}$, DAKO Diagnostics, Heverlee, Belgium). The next step consisted in a 30 min incubation with rabbit antiserum raised against horseradish peroxidase (Laboratory of Hormonology, Marloie, Belgium), followed by a 30 min incubation in presence of biotinylated swine anti-rabbit immunoglobulins antibodies (from DAKO). Texas Red labeling was completed by exposing cells for 30 min to Texas Red-conjugated streptavidin (Vector Laboratories, Burlingame, CA). After thorough rinses in PBS, the coverslips were mounted on glass slides using commercial anti-fading medium (Vectashield ${ }^{\circledR} ;$ Vector Laboratories). The cell preparations were examined on a Leitz Orthoplan microscope equipped with a Ploem system for epi-illumination. Texas Red fluorescence was examined at an excitation wavelength of $596 \mathrm{~nm}$ and an emission wavelength of $615 \mathrm{~nm}$.

\section{ERE-dependent transcriptional activity}

MVLN (MCF-7 stably transfected with pVit-tk-Luc reporter plasmid) (Pons et al., 1990) : After treatment with CaM antagonists, $E_{2}$, ER $\alpha 17 p$ or ER $\alpha 17 p$ analogs, cells were washed 2 times with PBS. Luciferase activity was measured in cell lysates by 
luminometry using Luciferase Assay System (Promega) according to a protocol described previously (Seo et al., 2000).

Evsa-T (ER-negative, PgR-positive breast cancer cell line) (Borras et al., 1997) : Cells, seeded in 6-well plates in the absence of antibiotics, were transiently transfected with ER constructions (pcDNA3-ERwt or pcDNA3-ER $\Delta$ ER $\alpha 17 p$ ) and reporter plasmids Vit-tk-Luc (ERE-mediated expression of firefly luciferase) and pRLtk (basal expression of Renilla luciferase). Two $\mu \mathrm{g} /$ well of pcDNA3-ERwt or pcDNA3-ER $\Delta$ ER $\alpha 17 \mathrm{p}$ and Vit-tk-Luc, and $400 \mathrm{ng} /$ well of pRL-tk were transfected using FuGENE 6 (Roche Applied Science). Sixteen hours after transfection, cells were treated for 24 additional hours with $0.1 \mathrm{nM} \mathrm{E}_{2}$ and / or $10 \mu \mathrm{M}$ ER $\alpha 17 \mathrm{p}$. Cells were then lysed and luciferase activities measured using Dual-Luciferase Reporter Assay System (Promega). Luciferase responses were normalized with respect to Renilla luciferase activity.

\section{Cells growth measurement}

ER-positive (MCF-7, T47D, IBEP-1, IBEP-3, BT-20) (de Longueville et al., 2005) and ER-negative (MDA-MB-231, MDA-MB-453, Evsa-T, HS-578T, SKBR-3) breast cancer cell lines (for review : Lacroix and Leclercq, 2004) were seeded in 96-well plates (3000 cells/well). Cells were then treated with $E_{2}$ at $0.1 \mathrm{nM}$ or ER $\alpha 17 \mathrm{p}$ and ER $\alpha 17 p$ analogs at $10 \mu \mathrm{M}$ for 24,48 , and 72 hours. Cell growth was measured by crystal violet staining (Journe et al., 2004). Briefly, cell cultures were gently washed once with PBS, fixed with $1 \%$ glutaraldehyde in PBS (15 min, room temperature) and stained with $0.1 \%$ crystal violet ( $w / v$ in $d_{d d H_{2}} \mathrm{O} ; 30$ min, room temperature). After 
removal of excess dye by rinsing under gently running tap water, cell-bound crystal violet was extracted with $1 \%$ Triton $\mathrm{X}-100\left(\mathrm{v} / \mathrm{v}\right.$ in $\mathrm{ddH}_{2} \mathrm{O}$; room temperature, under agitation) and measured by spectrometry at $550 \mathrm{~nm}$.

\section{Statistical analysis}

Statistical analysis was performed by ANOVA, followed by post-hoc Tukey test to assess differences between selected groups (SPSS software). Significance level was arbitrarily set at a $p$ value of 0.05 . 


\section{RESULTS}

\section{Ability of ER $\alpha 17 p$ to antagonize ER-CaM association}

When this study was initiated, the precise location of the CaM binding site in ER was still not established. Yet, an amino acid sequence located at the boundary between $D$ and $E$ domains of ER ( $P_{293}$ SPLMIKRSKKNSLALS $\left.{ }_{309}\right)$ was suspected to be involved in receptor interaction with CaM (Bouhoute and Leclercq, 1995; Castoria et al., 1988). Thus, we utilized a panel of antibodies raised against different ER epitopes (Fig. 1A) in order to evaluate the implication of this part of the receptor in its association with CaM. By doing this, we found that only antibodies raised against the junction between $\mathrm{D}$ and $\mathrm{E}$ domains (i.e. G-20 and AER-308) impeded the binding of a highly purified preparation of recombinant hER to CaM-Sepharose (Fig. 1B). Of note, no effect of these two antibodies on $\left[{ }^{3} \mathrm{H}\right] \mathrm{E}_{2}$ binding parameters was recorded by Scatchard plot analysis (data not shown), excluding the possibility that they might interfere with receptor binding properties. These observations prompted us to synthesize a peptide containing the suspected CaM binding motif (ER $\alpha 17 p$; $\mathrm{P}_{295}$ LMIKRSKKNSLALSLT 311 ; Fig. 1C). It should be stressed here that our option has been recently validated by other investigators who indeed demonstrated the implication of this motif in CaM recruitment, by using various ER mutant constructions (Li et al., 2005).

As could be expected, ER $\alpha 17 p$ inhibited ER-CaM association, since at $10 \mu \mathrm{M}$ it decreased the binding of hER to CaM-Sepharose (Fig. 2). In this respect, its effect was similar to that of two CaM inhibitors (calmidazolium and ophiobolin A) taken as 
reference compounds. Surprisingly and for unknown reasons, another CaM inhibitor (W-7) failed to exhibit antagonistic activity (Fig. 2). Of note, these observations were reproduced with $\left[{ }^{3} \mathrm{H}\right] \mathrm{E}_{2}$-bound hER (inhibition of ER binding to immobilized CaM: 54 $\%, 12 \%, 61 \%$ and $41 \%$ for calmidazolium, W-7, ophiobolin A and ER $17 p$, respectively, all compounds at $10 \mu \mathrm{M})$. Hence, under our experimental conditions, $\mathrm{E}_{2}$ did not modify the ability of ER $\alpha 17 p$ to inhibit the binding of ER to CaM-Sepharose.

The ability of ER $\alpha 17 p$ to directly interact with CaM was checked by a fluorescencebased binding assay using dansylated CaM. In this assay, a CaM kinase II peptide, used as a reference, produced a characteristic increase in fluorescence intensity (Fig. 3A). ER $\alpha 17 p$ also induced an increase of dansylated CaM fluorescence. However, as compared to the CaM kinase II peptide, a four-fold higher concentration of ER $\alpha 17 p(1 \mu \mathrm{M} v s 0.25 \mu \mathrm{M})$ was required to achieve a noticeable augmentation of the fluorescence signal, indicating a lower binding affinity of ER $\alpha 17 p$ versus the reference peptide. Accordingly, we observed that ER $\alpha 17 \mathrm{p}$ up to $20 \mu \mathrm{M}$ had no antagonistic activity toward a CaM-dependent cyclic AMP phosphodiesterase, while the CaM kinase II peptide acted as a potent inhibitor at largely lower concentrations (IC50 of $22 \pm 5 n M ; n=3$; Fig. 3B). Altogether, our observations suggested that ER $\alpha 17 p$ antagonizes ER-CaM interaction without drastically affecting CaM-mediated processes. Toxicity tests confirmed this interpretation. Thus, MTT assays performed on MCF-7 cells exposed to ER $\alpha 17 p$ at $10 \mu \mathrm{M}$ failed to disclose a decrease of metabolic activity even after prolonged treatment, while classical CaM inhibitors (calmidazolium, W-7 and ophiobolin A) displayed a detectable inhibitory effect at equivalent or lower concentrations (Fig. 4). Of note, ER $\alpha 17 \mathrm{p}$ at $10 \mu \mathrm{M}$ induced after 
48 hours an increase of mitochondrial activity which, as shown below, could be relevant to a growth stimulation.

Interference of ER $\alpha 17 p$ with the formation of intracellular ER-CaM complexes was finally established by co-immunoprecipitation with an anti-ER antibody in MCF-7 cells extracts (Fig. 5). After two hours of cell treatment with ER $\alpha 17 p$, CaM level decreased in the co-immunoprecipitate while the amount of ER remained constant, demonstrating thereby the dissociation of ER-CaM complexes. The observation of a similar phenomenon with cells treated with calmidazolium and ophiobolin A at nontoxic concentrations confirmed the validity of this assay. Of note, these treatments affected neither ER level nor that of CaM in whole cell lysates (data not shown).

\section{ER $\alpha 17 p$-induced ER down regulation and ERE-dependent transcription}

Exposure of MCF-7 cells to ER $\alpha 17 \mathrm{p}$ for 24 hours resulted in a dose-dependent loss of their capacity to accumulate $\left[{ }^{3} \mathrm{H}\right] \mathrm{E}_{2}(\mathrm{IC} 50=5.3 \mu \mathrm{M} ; \mathrm{n}=3 ;$ Fig. $6 \mathrm{~A})$. As shown by Scatchard plot analysis (Fig. 6B), this phenomenon was associated with a decrease of binding sites (Bmax) without substantial change in the dissociation constant of the binding reaction $(K d)$. A similar observation, suggestive of a down regulation process, was also recorded with ophiobolin $\mathrm{A}$ at $0.5 \mu \mathrm{M}$ (data not shown). We were therefore not surprised to observe that ER $\alpha 17 \mathrm{p}$-induced loss of estrogen binding capacity was correlated with a decrease of receptor level, which was evidenced by both Western blot analysis (Fig. 6D) and immunofluorescence microscopy (Fig. 6E). However, the loss of binding capacity persisted even when ER degradation was prevented by the proteasome inhibitor MG-132 (Fig. 6C), as shown previously for ER ligands (Laios et 
al., 2005; Seo et al., 2006). In fact, binding capacity decreased largely before ER degradation (i.e. after one hour of treatment; data not shown), suggesting that it may result from a conformational change preceding the proteasomal degradation. Hence, early ER conformational changes commonly induced by ligands seem also to be provoked by ER $\alpha 17 p$.

A link between agonist-induced proteasomal degradation of ER and its EREdependent transcriptional activity has been proposed in the recent literature (Reid et al., 2003; Metivier et al., 2003; Yan et al., 2003; Laios et al., 2005). In the current study, experiments performed with MCF-7 cells stably transfected with a Vit-tk-Luc reporter gene (MVLN cells) exposed to $10 \mu \mathrm{M}$ of ER $\alpha 17 \mathrm{p}$ revealed that the $\mathrm{ER} \alpha 17 \mathrm{p}$ induced ER down regulation was associated with a stimulation of ERE-dependent transactivation (mean $=179 \pm 11 \% ; n=8 ;$ Fig. 7 ). This result was in sharp contrast with the finding that, under the same experimental conditions, CaM inhibitors either were ineffective or produced a slight inhibition of ER-mediated gene transactivation. Hence, ER $\alpha 17 p$ seemed to be endowed with an estrogen-like activity without exerting a major effect on CaM. This was confirmed by the fact that ER $\alpha 17 p$ at 10 $\mu \mathrm{M}$ enhanced the expression of two estrogen-dependent endogenous genes after 24 hours of treatment (progesterone receptor and Ps2 mRNA ; $226 \%$ and $272 \%$ respectively). Of note, co-treatment with $E_{2}$ and $E R \alpha 17 p$ failed to exhibit any additive effect. On the other hand, calmodulin inhibitors, probably through their cytotoxicity, slightly decrease $\mathrm{E}_{2}$-enhanced transcription.

Assessment of CaM-independent mechanisms in ER 1 17p-mediated ER regulation 
Data described above led us to concentrate on the actual involvement of CaM in the mechanism underlying the agonis tic activity of ER $\alpha 17 \mathrm{p}$. The ER motif corresponding to $E R \alpha 17 p$ is, indeed, a region undergoing post-translational modifications critical for various physiological processes which are not necessarily CaM-dependent i.e. phosphorylation on $S_{305}$ (Wang et al., 2002) and $T_{311}$ (Lee and Bai, 2002), acetylation on $\mathrm{K}_{299}, \mathrm{~K}_{302}$ and $\mathrm{K}_{303}$ (Wang et al., 2001), SUMOylation (Sentis et al., 2005), proteolysis ( $\mathrm{K}_{299} \mathrm{RSKK}_{303}$ motif) (Seielstad et al., 1995). Furthermore, the ER $\alpha 17 \mathrm{p}$ sequence harbors a nuclear localization signal (NLS; $\mathrm{K}_{299} \mathrm{RSKK}_{303}$ ) (Picard et al., 1990; Ylikomi et al., 1992).

In order to assess the importance of $\mathrm{CaM}$ in $\mathrm{ER} \alpha 17 \mathrm{p}$-mediated agonistic responses, we synthesized two analogs where lysines $K_{302}$ and $K_{303}$, reported to be essential for CaM binding to ER (Garcia Pedrero et al., 2002), were substituted by alanines (ER $\alpha 17 p A A)$ or glycines (ER $\alpha 17 p G G)$. As expected, these two analogs failed to bind CaM (Fig. 8A and Fig. 8B bottom) and, by contrast to ER $\alpha 17 p$, did not compete with ER for the binding to CaM-Sepharose (Fig. 8B top). We considered, therefore, that they were appropriate tools for unraveling potential CaM-independent interactions involved in ER $\alpha 17 p$-induced ER activation.

As inferred from the measurement of $\left[{ }^{3} \mathrm{H}\right] \mathrm{E}_{2}$ binding capacity (Fig. 9A) and ER level (Fig. 9B) in MCF-7 cells, ER $\alpha 17 \mathrm{pAA}$ and $\mathrm{ER} \alpha 17 \mathrm{pGG}$ induced $\mathrm{ER}$ down regulation with a slightly higher efficiency than ER $\alpha 17 p$. These analogs also increased EREdependent transactivation in MVLN cells (Fig. 10), providing evidence that the effect of $E R \alpha 17 p$ on ER regulation was not strictly related to a dissociation of ER-CaM 
complexes. According to this view, one may assume that ER $\alpha 17 p$ did not strongly affect the initial CaM-dependent steps of ER-mediated transactivation but rather, the subsequent events culminating in ER degradation. ER $\alpha 17 p A A$ and ER $\alpha 17 p G G$ would exclusively promote the latter events.

\section{Growth stimulation of ER-positive cell lines induced by ER $\alpha 17 p$ and its analogs}

At this stage, it appeared crucial to evaluate the possibility that ER $\alpha 17 p$ and its analogs might exert an effect on the growth of ER-positive cell lines. As illustrated in Fig. 11, the three peptides at $10 \mu \mathrm{M}$ stimulated the proliferation of a panel of five ERpositive breast cancer cell lines (MCF-7, T47D, IBEP-1, IBEP-3 and BT-20) ( $\mathrm{E}_{2}$ was included as a positive control). Stimulatory properties of these peptides varied among investigated cell lines, reflecting their biological differences (Lacroix and Leclercq, 2004) ; peptide analogs appeared to be more efficient than ER $\alpha 17 p$ in this regard. By contrast, the peptides did not affect the proliferative activity of ER-negative cell lines (MDA-MB-231, MDA-MB-453, Evsa-T, HS-578T and SKBR-3). These experiments unambiguously established the implication of ER in the mechanism of action of ER $\alpha 17 p$ and excluded any possibility that the observations reported above might result from non-specific effects. The finding that a panel of eight peptides derived from DNA and ligand binding domains of ER (i.e. $R_{211}-M_{220}, P_{222}-K_{231}, D_{332}-L_{346}, K_{363^{-}}$ $V_{377}, K_{417}-A_{431}, S_{456}-H_{474}, A_{491}-L_{504}$ and $\left.D_{538}-A_{551}\right)$ failed to similarly stimulate MCF-7 cells growth (data not shown) is another proof of the specificity.

\section{Molecular mechanism underlying ER $\alpha 17 p$-induced activation of ER}


We finally addressed the mechanism involved in the action of ER $\alpha 17 p$ on ERpositive cell lines. For that purpose, a transient transfection of the ER-negative, PgRpositive breast cancer cell line Evsa-T (Borras et al., 1997) with an ER variant lacking the ER $\alpha 17 p$ motif (ER $\triangle E R \alpha 17 p)$ was performed. This transfection resulted in an enhanced expression of a co-transfected ERE-dependent reporter gene (Fig. 12). Strikingly, reporter gene expression in cells co-transfected with this ER variant was amplified neither by $E_{2}$, nor by $E R \alpha 17 p$, while control cells transfected with wild type ER displayed an usual behavior (as described in MVLN cells). Hence, agonistic responses described here seem to be due to the disruption of a repressive effect to which the $\mathrm{P}_{295}-\mathrm{T}_{311}$ motif largely contributes. This statement provides an explanation to data reported by Li et al. (2005), which showed that various deletions in the D/E border region were associated with high basal, $\mathrm{E}_{2}$-insensitive transcriptional activity. 


\section{DISCUSSION}

Small synthetic peptides harboring the canonical motif of co-activators ( $L x x L L)$ or corepressors $(L x x(H / I) I x x(L / I))$ have been found to enhance or repress, respectively, ERE-dependent transcription (Xu et al., 2002; lannone et al., 2004; Rodriguez et al., 2004; Shao et al., 2004). Hence, peptides that may interfere with co-regulator recruitment have proven to be useful tools for evaluating the mechanism by which ER mediates transcription. Data reported here extend this concept to peptides exhibiting ER regulatory motifs. Indeed, we clearly show that ER $\alpha 17 p$ increases ER-mediated transcription in breast cancer cell lines, leading to a stimulation of their growth.

The $P_{295}-T_{311}$ sequence of $E R$, to which ER $\alpha 17 p$ corresponds, is a multifaceted regulatory platform subjected to several post-translational modifications, indicative of its importance in ER regulation. By a computer-based protein modeling approach (Jacquot et al., 2006), we recently identified a putative regulatory intramolecular interaction between a motif included in the $P_{295}-T_{311}$ sequence (aa 301-311) and the helix $\mathrm{H} 4$ which is located within a region known to recruit co-regulators $(\mathrm{H} 3-\mathrm{H} 5)$ (Warnmark et al., 2002; Kong et al., 2005). Hence, the estrogen-like activity of ERa17p might stem from its ability to interfere with this regulatory mechanism. According to our data, CaM by specifically interfering with the $P_{295}-T_{311}-H 4$ interaction would most probably abrogate an associated specific repressive effect, perhaps with concomitant release of bound co-repressor(s) and/or recruitment of coactivator(s). This view is supported by the fact that other peptides outside the region covered by ER $\alpha 17 p$ does not have its impact on cell growth. Ongoing studies are carried out to assess this hypothesis. 
CaM has been reported to be overexpressed in breast cancers, suggesting its implication in the development of the disease (Singer et al., 1976). This concept is somehow supported by our investigations, inasmuch as a high amount of CaM may favor the activation of ER and lead in fine to an increased ER-mediated transactivation and an enhanced cell proliferation. This postulate may also explain why CaM antagonists impede the growth of breast cancer cells and synergistically augment the antiproliferative action of antiestrogens (Strobl et al., 1994; Wei et al., 1983).

Conventional CaM inhibitors maintain $\mathrm{CaM}$ in an inactive status and most probably abrogate its binding to ER, blocking thereby the association of the latter with ERE, i.e. the initial step of the transcription cycle. In contrast to CaM inhibitors which have been reported to impede ER-mediated transactivation (Biswas et al., 1998; Garcia Pedrero et al., 2002; Li et al., 2005), synthetic peptides containing the $P_{295}-T_{311}$ sequence would confer to ER an activated conformation similar to that induced by CaM, even if they are unable to directly interact with CaM.

$\mathrm{K}_{302}$ and $\mathrm{K}_{303}$ of $\mathrm{ER}$ have been reported to be crucial for the recruitment of CaM (Garcia Pedrero et al., 2002). Our finding that the ER $\alpha 17 p A A$ and ER $\alpha 17 p G G$ analogs of ER $\alpha 17 p$ fail to associate with CaM confirms the importance of these two lysines. The basic $\varepsilon$-amino group in these amino acids may be taken as responsible for their capacity to attract CaM. In this view, a missense point mutation causing the substitution of an arginine $(R)$ for $K_{303}$ has been detected in hyperplastic and neoplastic breast lesions (Fuqua et al., 2000; Herynk and Fuqua, 2004; Conway et 
al., 2005). Studies performed with MCF-7 cells transfected with such a K303R mutant revealed that this mutation induces an increase of sensitivity to estradiol with regard to cell proliferation. This mutation also favors the recruitment of the TIF-2 co-activator at lower $E_{2}$ concentration than the wild type receptor (Fuqua et al., 2000). Since arginine is more basic than lysine, one may surmise that the hyperactivity of the K303R mutant may be relevant to a higher ability to attract CaM, with as a consequence a facilitated conversion of the receptor into its activated form.

ER-mediated transcription involves cyclic association / dissociation of the receptor with / from specific targets (i.e. EREs, heat shock proteins, histone acetyltransferases of the CBP/p300 family, transcription factors, ubiquitin ligases...) (for review : Leclercq et al., 2006; Nawaz and O'Malley, 2004). The ability of CaM to enhance ER binding to EREs suggests its involvement in the association of the receptor with the promoter regions of target genes. One may logically postulate that this initial step of the transactivation cycle requires a receptor where all regulatory motifs (zinc fingers, AF-1 and AF-2 domains...) are fully operational. The ability of CaM to prevent ER ubiquitination (Li et al., 2006) should logically meet this requirement. This protective effect of CaM would progressively vanish, leading to the transfer of the receptor to the ubiquitin / proteasome system. Hence, CaM-induced activation would only affect the stability of the receptor at a step beyond its anchorage to the promoter. In the context of this model, synthetic peptides like ER $\alpha 17 p$ would favor this activation process. Whether proteasomal degradation of ER provokes the emergence of small peptides with regulatory properties similar to those of ER $\alpha 17 p$ is another issue that we are currently investigating. Indeed, the production of such peptides may be a key determinant of the basal (ligand-independent) transcriptional activity of ER. 
As illustrated here, an ER deletion mutant lacking the $\mathrm{P}_{295}-\mathrm{T}_{311}$ sequence exhibits an enhanced estrogen independent transcriptional activity. Interestingly, this property has already been recorded for other mutations affecting this region of the receptor ( $\mathrm{Li}$ et al., 2005). The potential lack of operative NLS in such mutants appears, therefore, not detrimental to ER-mediated transcription, in agreement with studies previously reported (Picard et al., 1990; Ylikomi et al., 1992). ER activation most probably favors the exposure of other NLS or similar structural motifs promoting the transport of the receptor across the nuclear membrane.

The design of peptide mimics able to modify the ability of ER to recruit co-regulators has been proposed as an alternative to conventional estrogen- or antiestrogen-based hormonotherapy (Rodriguez et al., 2004; Shao et al., 2004). This approach, which would be especially valuable for the treatment of pathologies associated with receptor insensitivity to ligand binding, is still in its infancy. Our study supports such a pharmacological approach, even if the concentration of ER $\alpha 17 p$ and its analogs required for the onset of a significant response is high. This drawback, also found for LxxLL mimics (lannone et al., 2004) most probably results from a low cellular uptake. Thus, there is an obvious need for an improvement of pharmacokinetic properties resulting in a better intracellular penetration of small peptides with potential therapeutic activity. Synthesis of non-peptide hydrophobic drugs with similar competitive properties for ER (Rodriguez et al., 2004; Shao et al., 2004) is another approach to avoid this pitfall. 
The current study is mainly focused on ER transcriptional activity in breast cancer cells. One may wonder whether similar results would be obtained with other estrogen target cells, in particular cells where distribution and shuttling of ER are different. Beside, recent investigations have clearly shown that ER does not only elicit genomic responses, but also triggers rapid, so-called non-genomic responses via signal transduction cascades (Cheskis, 2004; Singh and Kumar, 2005; Evinger and Levin, 2005; Kampa and Castanas, 2006). Studies aimed at knowing whether ER $\alpha 17 p$ also activates ER-mediated non-genomic responses are planned in the near future. Furthermore, future investigations should also examine the potential impact of intracellular $\mathrm{Ca}^{2+}$ spikes on the mechanisms described here (co-treatment with $\mathrm{Ca}^{2+}$ channel modulators). Hence, our observations open new avenues in the study of the mechanisms by which estrogens (and most probably other steroid hormones) provoke specific responses in target tissues. 


\section{ACKNOWLEDGMENTS}

This study received financial support from the Fonds Jean-Claude Heuson, the Fondation MEDIC, the Fonds CGRI/CNRS/FNRS (Grant $n^{\circ} 18217$ ), the Belgian Fund for Medical Scientific Research (Grant $n^{\circ} 3.4512 .03$ ). D. Gallo is a recipient of a grant from the Fonds Jean-Claude Heuson. G. Laurent is Senior Research Associate of the National Fund for Scientific Research (Belgium). We thank C. Pereda Meira, R. Mukandayambaje and M Depuydt for their active contribution in this work and J. Richard for her excellent secretarial and editorial assistance. We are also indebted to J. Van Beeumen and B. Devreese for mass spectrometry analysis and L. Lagneaux and $\mathrm{H}$. Id Boufker for their kind help in PCR experiments. 


\section{REFERENCES}

Atherton, E., Sheppard R.C., 1989. Solid phase peptide synthesis: a practical approach. IRL Press, Oxford.

Biswas, D.K., Reddy, P.V., Pickard, M., Makkad, B., Pettit, N., Pardee, A.B., 1998. Calmodulin is essential for estrogen receptor interaction with its motif and activation of responsive promoter. J. Biol. Chem. 273, 33817-33824.

Borras, M., Lacroix, M., Legros, N., Leclercq, G., 1997. Estrogen receptornegative/progesterone receptor-positive Evsa-T mammary tumor cells: a model for assessing the biological property of this peculiar phenotype of breast cancers. Cancer Lett. 120, 23-30.

Bouhoute, A., Leclercq, G., 1994. Estradiol derivatives bearing the side-chain of tamoxifen antagonize the association between the estrogen receptor and calmodulin. Biochem. Pharmacol. 47, 748-751.

Bouhoute, A., Leclercq, G., 1995. Modulation of estradiol and DNA binding to estrogen receptor upon association with calmodulin. Biochem. Biophys. Res. Commun. 208, 748-755.

Brohee, R., Nonclercq, D., Journe, D.N., Toubeau, G., Falmagne, P., Leclercq, G., Heuson-Stiennon, J.A., Laurent, G., 2000. Demonstration of estrogen receptors and of estrogen responsiveness in the HKT-1097 cell line derived from diethylstilbestrol-induced kidney tumors. In Vitro Cell. Dev. Biol. Anim. 36, 640649.

Castoria, G., Migliaccio, A., Nola, E., Auricchio, F., 1988. In vitro interaction of estradiol receptor with Ca2+-calmodulin. Mol. Endocrinol. 2, 167-174.

Cheskis, B.J., 2004. Regulation of cell signalling cascades by steroid hormones. J. Cell. Biochem. 93, 20-27. 
Conway, K., Parrish, E., Edmiston, S.N., Tolbert, D., Tse, C.K., Geradts, J., Livasy, C.A., Singh, H., Newman, B., Millikan, R.C., 2005. The estrogen receptor-alpha A908G (K303R) mutation occurs at a low frequency in invasive breast tumors: results from a population-based study. Breast Cancer Res. 7, R871-880.

de Longueville, F., Lacroix, M., Barbuto, A.M., Bertholet, V., Gallo, D., Larsimont, D., Marcq, L., Zammatteo, N., Boffe, S., Leclercq, G., Remacle, J., 2005. Molecular characterization of breast cancer cell lines by a low-density microarray. Int. J. Oncol. 27, 881-892.

Evans, R.M., 1988. The steroid and thyroid hormone receptor superfamily. Science $240,889-895$.

Evinger, A.J., 3rd, Levin, E.R., 2005 Requirements for estrogen receptor alpha membrane localization and function. Steroids 70, 361-363.

Fuqua, S.A., Wiltschke, C., Zhang, Q.X., Borg, A., Castles, C.G., Friedrichs, W.E., Hopp, T., Hilsenbeck, S., Mohsin, S., O'Connell, P., Allred, D.C., 2000. A hypersensitive estrogen receptor-alpha mutation in premalignant breast lesions. Cancer Res. 60, 4026-4029.

Garcia Pedrero, J.M., Del Rio, B., Martinez-Campa, C., Muramatsu, M., Lazo, P.S., Ramos S., 2002. Calmodulin is a selective modulator of estrogen receptors. Mol. Endocrinol. 16, 947-960.

Green, S., Walter, P., Kumar, V., Krust, A., Bornert, J.M., Argos, P., Chambon, P., 1986. Human oestrogen receptor cDNA: sequence, expression and homology to v-erb-A. Nature 320, 134-139.

Herynk, M.H., Fuqua, S.A., 2004. Estrogen receptor mutations in human disease. Endocr. Rev. 25, 869-898. 
lannone, M.A., Simmons, C.A., Kadwell, S.H., Svoboda, D.L., Vanderwall, D.E., Deng, S.J., Consler, T.G., Shearin, J., Gray, J.G., Pearce, K.H., 2004. Correlation between in vitro peptide binding profiles and cellular activities for estrogen receptor-modulating compounds. Mol. Endocrinol. 18, 1064-1081.

Imai, Y., Matsushima, Y., Sugimura, T., Terada, M., 1991. A simple and rapid method for generating a deletion by PCR. Nucleic Acids Res. 19, 2785.

Jacquot, Y., Gallo, D., Leclercq, G., 2006. Estrogen receptor alpha - Identification by a modeling approach of a potential polyproline II recognizing domain within the AF2 region of the receptor that would play a role of prime importance in its mechanism of action. J. Steroid Biochem. Mol. Biol. (article in press) doi:10.1016/j.jsbmb.2006.10.008

Journe, F., Chaboteaux, C., Dumon, J.C., Leclercq, G., Laurent, G., Body, J.J., 2004. Steroid-free medium discloses oestrogenic effects of the bisphosphonate clodronate on breast cancer cells. Br. J. Cancer 91(9), 1703-10.

Kaiser, E., Colescott, R.L., Bossinger, C.D., Cook, P.I., 1970. Color test for detection of free terminal amino groups in the solid-phase synthesis of peptides. Anal. Biochem. 34, 595-8.

Kampa, M., Castanas, E., 2006. Membrane steroid receptor signaling in normal and neoplastic cells. Mol. Cell. Endocrinol. 246, 76-82.

Kincaid, R.L., Vaughan, M., Osborne Jr, J.C., Tkachuk, V.A., 1982. Ca2+-dependent interaction of 5-dimethylaminonaphthalene-1-sulfonyl-calmodulin with cyclic nucleotide phosphodiesterase, calcineurin, and troponin I. J. Biol. Chem. 257, 10638-10643.

Knorr, R., Trzeciak, A., Bannwarth, W., Gillessen, D., 1989. New coupling reagents in peptide chemistry. Tetrahedron Lett. 30, 1927-30. 
Kong, E.H., Heldring, N., Gustafsson, J.A., Treuter, E., Hubbard, R.E., Pike, A.C., 2005. Delineation of a unique protein-protein interaction site on the surface of the estrogen receptor. Proc. Natl. Acad. Sci. U.S.A. 102, 3593-3598.

Lacroix, M., Leclercq, G., 2004. Relevance of breast cancer cell lines as models for breast tumours: an update. Breast Cancer Res. Treat. 83, 249-289.

Laios, I., Journe, F., Nonclercq, D., Vidal, D.S., Toillon, R.A., Laurent, G., Leclercq, G., 2005. Role of the proteasome in the regulation of estrogen receptor alpha turnover and function in MCF-7 breast carcinoma cells. J. Steroid. Biochem. Mol. Biol. 94, 347-359.

Leclercq, G., Lacroix, M., Laios, I., Laurent, G., 2006. Estrogen receptor alpha: impact of ligands on intracellular shuttling and turnover rate in breast cancer cells. Curr. Cancer Drug Targets 6, 39-64.

Lee, H., Bai, W., 2002. Regulation of estrogen receptor nuclear export by ligandinduced and p38-mediated receptor phosphorylation. Mol. Cell. Biol. 22, 58355845.

Li, L., Li, Z., Sacks, D.B., 2003. Calmodulin regulates the transcriptional activity of estrogen receptors. Selective inhibition of calmodulin function in subcellular compartments. J. Biol. Chem. 278, 1195-1200.

Li, L., Li, Z., Sacks, D.B., 2005. The transcriptional activity of estrogen receptor-alpha is dependent on Ca2+/calmodulin. J. Biol. Chem. 280, 13097-13104.

Li, L., Li, Z., Howley, P.M., Sacks, D.B., 2006. E6AP and calmodulin reciprocally regulate estrogen receptor stability. J. Biol. Chem. 281, 1978-1985.

Li, Z., Joyal, J.L., Sacks, D.B., 2001. Calmodulin enhances the stability of the estrogen receptor. J. Biol. Chem. 276, 17354-17360. 
Martin, P.M., Berthois, Y., Jensen, E.V., 1988. Binding of antiestrogens exposes an occult antigenic determinant in the human estrogen receptor. Proc. Natl. Acad. Sci. U.S.A. 85, 2533-2537.

McCague, R., Rowlands, M.G., Grimshaw, R., Jarman, M., 1994. Evidence that tamoxifen binds to calmodulin in a conformation different to that when binding to estrogen receptors, through structure-activity study on ring-fused analogues. Biochem. Pharmacol. 48, 1355-1361.

Metivier, R., Penot, G., Hubner, M.R., Reid, G., Brand, H., Kos, M., Gannon, F., 2003. Estrogen receptor-alpha directs ordered, cyclical, and combinatorial recruitment of cofactors on a natural target promoter. Cell 115, 751-763.

Nawaz, Z., O'Malley, B.W., 2004. Urban renewal in the nucleus: is protein turnover by proteasomes absolutely required for nuclear receptor-regulated transcription? Mol. Endocrinol. 18, 493-499.

Picard, D., Kumar, V., Chambon, P., Yamamoto, K.R., 1990. Signal transduction by steroid hormones: nuclear localization is differentially regulated in estrogen and glucocorticoid receptors. Cell Regul. 1, 291-299.

Pons, M., Gagne, D., Nicolas, J.C., Mehtali, M., 1990. A new cellular model of response to estrogens: a bioluminescent test to characterize (anti) estrogen molecules. Biotechniques 9, 450-459.

Reid, G., Hubner, M.R., Metivier, R., Brand, H., Denger, S., Manu, D., Beaudouin, J., Ellenberg, J., Gannon, F., 2003. Cyclic, proteasome-mediated turnover of unliganded and liganded ERalpha on responsive promoters is an integral feature of estrogen signaling. Mol. Cell. 11, 695-707. 
Rodriguez, A.L., Tamrazi, A., Collins, M.L., Katzenellenbogen, J.A., 2004. Design, synthesis, and in vitro biological evaluation of small molecule inhibitors of estrogen receptor alpha coactivator binding. J. Med. Chem. 47, 600-611.

Rossini, G.P., 1994. The quaternary structures of untransformed steroid hormone receptors: an open issue. J. Theor. Biol. 166, 339-353.

Rowlands, M.G., Parr, I.B., McCague, R., Jarman, M., Goddard, P.M., 1990. Variation of the inhibition of calmodulin dependent cyclic AMP phosphodiesterase amongst analogues of tamoxifen; correlations with cytotoxicity. Biochem. Pharmacol. 40, 283-289.

Rowlands, M.G., Grimshaw, R., Jarman, M., Bouhoute, A., Leclercq, G., 1997. Antagonism of estrogen receptor and calmodulin association by antiestrogens is not dependent on an interaction with calmodulin. Biochem. Pharmacol. 53, 241244.

Scatchard, G., 1949. The attraction of proteins for small molecules and ions. Ann. NY Acad. Sci. 51, 660-672.

Seielstad, D.A., Carlson, K.E., Kushner, P.J., Greene, G.L., Katzenellenbogen, J.A., 1995. Analysis of the structural core of the human estrogen receptor ligand binding domain by selective proteolysis/mass spectrometric analysis. Biochemistry. 34, 12605-12615.

Sentis, S., Le Romancer, M., Bianchin, C., Rostan, M.C., Corbo, L., 2005. SUMOylation of the estrogen receptor alpha hinge region regulates its transcriptional activity. Mol. Endocrinol. 19, 2671-2684.

Seo, H.S., Larsimont, D., Ma, Y., Laios, I., Leclercq, G., 2000. Regulation of estrogen receptor levels by ligand-induced release of compound(s) in MCF-7 cells. Mol. Cell. Endocrinol. 164, 19-29. 
Seo, H.S., DeNardo, D.G., Jacquot, Y., Laios, I., Vidal, D.S., Zambrana, C.R., Leclercq, G., Brown, P.H., 2006. Stimulatory effect of genistein and apigenin on the growth of breast cancer cells correlates with their ability to activate ER alpha. Breast Cancer Res. Treat. 99, 121-34.

Shang, Y., Hu, X., DiRenzo, J., Lazar, M.A., Brown, M., 2000. Cofactor dynamics and sufficiency in estrogen receptor-regulated transcription. Cell 103, 843-852.

Shao, D., Berrodin, T.J., Manas, E., Hauze, D., Powers, R., Bapat, A., Gonder, D., Winneker, R.C., Frail, D.E., 2004. Identification of novel estrogen receptor alpha antagonists. J. Steroid. Biochem. Mol. Biol. 88, 351-360.

Singer, A.L., Sherwin, R.P., Dunn, A.S., Appleman, M.M., 1976. Cyclic nucleotide phosphodiesterases in neoplastic and nonneoplastic human mammary tissues. Cancer Res. 36, 60-66.

Singh, R.R., Kumar R., 2005. Steroid hormone receptor signaling in tumorigenesis. J. Cell. Biochem. 96, 490-505.

Strobl, J.S., Peterson, V.A., W oodfork, K.A., 1994. A survey of human breast cancer sensitivity to growth inhibition by calmodulin antagonists in tissue culture. Biochem. Pharmacol. 47, 2157-2161.

Wang, C., Fu, M., Angeletti, R.H., Siconolfi-Baez, L., Reutens, A.T., Albanese, C., Lisanti, M.P., Katzenellenbogen, B.S., Kato, S., Hopp, T., Fuqua, S.A., Lopez, G.N., Kushner, P.J., Pestell, R.G., 2001. Direct acetylation of the estrogen receptor alpha hinge region by p300 regulates transactivation and hormone sensitivity. J. Biol. Chem. 276, 18375-18383.

Wang, R.A., Mazumdar, A., Vadlamudi, R.K., Kumar, R., 2002. P21-activated kinase1 phosphorylates and transactivates estrogen receptor-alpha and promotes hyperplasia in mammary epithelium. Embo J. 21, 5437-5447. 
Warnmark, A., Treuter, E., Gustafsson, J.A., Hubbard, R.E., Brzozowski, A.M., Pike, A.C., 2002. Interaction of transcriptional intermediary factor 2 nuclear receptor box peptides with the coactivator binding site of estrogen receptor alpha. J. Biol. Chem. 277, 21862-21868.

Wei, J.W., Hickie, R.A., Klaassen, D.J., 1983. Inhibition of human breast cancer colony formation by anticalmodulin agents: trifluoperazine, W-7, and W-13. Cancer Chemother. Pharmacol. 11, 86-90.

Xu, H.E., Stanley, T.B., Montana, V.G., Lambert, M.H., Shearer, B.G., Cobb, J.E., McKee, D.D., Galardi, C.M., Plunket, K.D, Nolte, R.T., Parks, D.J., Moore, J.T., Kliewer, S.A., Willson, T.M., Stimmel, J.B., 2002. Structural basis for antagonistmediated recruitment of nuclear co-repressors by PPARalpha. Nature 415, 813817.

Yan, F., Gao, X., Lonard, D.M., Nawaz, Z., 2003. Specific ubiquitin-conjugating enzymes promote degradation of specific nuclear receptor coactivators. Mol. Endocrinol. 17, 1315-1331.

Ylikomi, T., Bocquel, M.T., Berry, M., Gronemeyer, H., Chambon, P., 1992. Cooperation of proto-signals for nuclear accumulation of estrogen and progesterone receptors. Embo J. 11, 3681-3694. 
FIGURE LEGENDS

Figure 1 : Influence of anti-ER antibodies on ER-CaM binding. A: ER regions recognized by D-12, H-184, G-20, AER-308, F-10 and HC-20 anti-ER antibodies. B: ER - CaM-Sepharose binding assay. $\left[{ }^{3} \mathrm{H}\right] \mathrm{E}_{2}$ labeled hER preparations were incubated with CaM-Sepharose in the absence (total binding ; $\bullet$ ) or presence (- or ...... ) of a given anti-ER antibody. Non-specific binding (NSB ; ***) was established with a 200 fold excess of unlabeled $E_{2}$. After washing (fractions 1 to 3 ) matrixes were eluted with EDTA (fractions 4 to 6 ) in order to evaluate the potential influence of antibodies on the association of ER to CaM. Grey surfaces represent the decrease of CaM-bound ER. The figure refers to an experiment performed twice. $\mathrm{C}$ : Aminoacids sequence of ER $\alpha 17 p$ and location of the corresponding motif with in ER.

Figure 2 : Inhibition of ER - CaM-Sepharose binding by ER $\alpha 17 p$. Preparations of recombinant hER were incubated with CaM-Sepharose in the absence (control) or presence of $10 \mu \mathrm{M}$ of CaM antagonists (calmidazolium, W-7 and ophiobolin A) or of ER $\alpha 17 p$. After washing, matrixes were eluted with EDTA and levels of released ER assessed by Western blot analysis using F-10 anti-ER antibody. The figure is representative of three independent experiments.

Figure 3 : Lack of strong interaction between ER $\alpha 17 p$ and CaM. A : Measurement of ER $\alpha 17 p-$ CaM binding by a dansylated CaM fluorescence assay. Fluorescence intensity was measured in the absence (control ; $\rightarrow-$ ) or presence of EGTA $(\cdot-\cdot)$. ER $\alpha 17 p$ at $1 \mu \mathrm{M}(-\rightarrow-)$ and CaM kinase II peptide (positive control ; --.--) at $0.25 \mu \mathrm{M}$ produced a significant increase in fluorescence intensity. B : Cyclic 
AMP phosphodiesterase activity measurement. Increasing amounts of ER $\alpha 17 p$ $(\longrightarrow-)$ and CaM kinase II peptide (--.--) were added to a phosphodiesterase preparation in the presence of $\mathrm{CaM}$ and $\left[{ }^{3} \mathrm{H}\right] \mathrm{cAMP}$ (substrate). After incubation, tritiated adenosine produced by $\left[{ }^{3} \mathrm{H}\right] \mathrm{cAMP}$ hydrolysis and subsequent cleavage of $\left[{ }^{3} \mathrm{H}\right]$ AMP was measured by liquid scintillation counting.

Figure 4 : Effect of CaM inhibitors and ER $\alpha 17 p$ on MCF-7 cell viability. MCF-7 cells were incubated for $6,16,24$ and 48 hours in the absence (control $=100 \%$ ) or presence of calmidazolium (1 and $5 \mu \mathrm{M}), \mathrm{W}-7$ ( 5 and $10 \mu \mathrm{M})$, ophiobolin A (0.5 and 1 $\mu \mathrm{M})$ or $\mathrm{ER} \alpha 17 \mathrm{p}(1$ and $10 \mu \mathrm{M})$. After treatment, cell viability was measured by MTT assay. Results were expressed in \% absorbance (mean \pm SD) of control. Measurements were performed in sixplicate. The figure refers to an experiment performed twice.

Figure 5 : Inhibition of endogenous ER-CaM association by ER $\alpha 17 p$. MCF-7 cells were treated for two hours with CaM antagonists ( $1 \mu \mathrm{M}$ calmidazolium, $5 \mu \mathrm{M} \mathrm{W}$ 7 and $0.5 \mu \mathrm{M}$ ophiobolin A) or with $10 \mu \mathrm{M}$ of ERa17p. After cell lysis, ER-CaM complexes were co-immunoprecipitated with F-10 anti-ER antibody. Level of ER and CaM were then revealed by Western blot. The figure shows an immunoblot representative of two independent experiments and densitometric analys is values (mean ratio of CaM / ER optical densities). Control, untreated cells.

Figure 6 : ER $\alpha 17 p$-induced ER down regulation. A : Loss of estrogen binding capacity. MCF-7 cells were incubated with ER $\alpha 17 p$ at concentrations ranging from 1 to $50 \mu \mathrm{M}$. After 24 hours of treatment, binding capacity was measured by incubation 
of the cells with $\left[{ }^{3} \mathrm{H}\right] \mathrm{E}_{2}$ (whole cell assay). Each point represents the mean $\pm \mathrm{SD}$ of three separate experiments with determinations performed in duplicate. B : Influence on $\left[{ }^{3} \mathrm{H}\right] \mathrm{E}_{2}$ binding parameters. MCF-7 cells were incubated for 24 hours in the absence (control) or presence of $10 \mu \mathrm{M}$ ER $\alpha 17 p$ before exposure to $\left[{ }^{3} \mathrm{H}\right] \mathrm{E}_{2} . K d$ and Bmax parameters were determined by Scatchard plot analysis. Representative results of an experiment performed four times, where $K d$ ranged from 0.08 to 0.26 $\mathrm{nM}$ (Bmax decrease induced by ER $\alpha 17 \mathrm{p}$ was $52 \% \pm 12$ as compared to control). C : Loss of estrogen binding capacity in the presence of MG-132. MCF-7 cells were incubated for 6 hours in the absence (control) or presence of $10 \mu \mathrm{M}$ ER $\alpha 17 \mathrm{p}$ with or without $M G-132$ at $1 \mu \mathrm{M}$ before exposure to $\left[{ }^{3} \mathrm{H}\right] \mathrm{E}_{2}$. Binding parameters were determined as described above. The figure is representative of four independent experiments in which $K d$ ranged from 0.09 to $0.23 \mathrm{nM}$. In the absence of proteasome inhibitor, the Bmax decrease induced by ER $\alpha 17 p$ was $41 \% \pm 7$ as compared to control. In the presence of MG-132, Bmax was decreased by $43 \% \pm 16$. D : Western blot analysis. MCF-7 cells were cultured for 6,24 and 48 hours in the absence (control) or presence of either a CaM antagonist ( $1 \mu \mathrm{M}$ calmidazolium, $5 \mu \mathrm{M} \mathrm{W}-7$ and $0.5 \mu \mathrm{M}$ ophiobolin A) or ER $\alpha 17 \mathrm{p}$ at 1 and $10 \mu \mathrm{M}$. Western blots were carried out using D-12 anti-ER and MAB1501R anti-actin antibodies. Immunoblots are representative of three independent experiments. Densitometric analysis values (ratio of ER / actin ODs) are given and expressed as percentages of control. E : ER demonstration by immunofluorescence microscopy. Cells were incubated for 24 hours in the absence (control) or presence of $10 \mu \mathrm{M}$ ER $\alpha 17 \mathrm{p}$. ER was demonstrated by immunofluorescence staining using $\mathrm{HC}-20$ antibody. 
Figure 7 : Influence of ER $\alpha 17 p$ on ERE-dependent transcription. MVLN cells were incubated for 24 hours in the absence (control) or presence of CaM antagonist ( $1 \mu \mathrm{M}$ calmidazolium, $5 \mu \mathrm{M} \mathrm{W}-7$ and $0.5 \mu \mathrm{M}$ ophiobolin $\mathrm{A}$ ) or ER $\alpha 17 \mathrm{p}$ at $10 \mu \mathrm{M}$, with or without $0.1 \mathrm{nM} \mathrm{E}_{2}$. Luciferase activity was assayed in cellular extracts by luminometry and emitted light signals were expressed in arbitrary units (relative luciferase units, RLU) per mg protein. Data refer to the mean value $( \pm S D)$ of, at least, three independent experiments with measurements performed in duplicate and are given as percentage of controls. * Significantly higher as compared to control.

Figure 8 : Failure of ER $\alpha 17 p$ analogs to inhibit ER-CaM association. A : ER $\alpha 17 p$, ER $\alpha 17 p A A$ and $E R \alpha 17 p G G$ all at $10 \mu \mathrm{M}$ were incubated with Sepharose 4B (for assessment of non-specific adsorption) or CaM-Sepharose matrixes. After washing, and elution with EDTA, bound and unbound peptides were separated by electrophoresis and revealed by Sypro Ruby staining. The figure, representative of two independent experiments, demonstrates that, in contrast to ER $\alpha 17 p$, the two analogs do not bind to CaM-Sepharose. Note also, for all peptide, the absence of adsorption on Sepharose. B : Lack of antagonism of ER $\alpha 17 p$ analogs toward ERCaM association. Preparations of recombinant hER were incubated with CaMSepharose in the absence (control) or presence of $10 \mu \mathrm{M}$ of ER $\alpha 17 p$, ER $\alpha 17 p A A$ and ER $\alpha 17$ pGG. After washing, matrixes were eluted with EDTA and levels of bound ER assessed by Western blot analysis using F-10 anti-ER antibody (top), while the level of bound peptides was revealed by silver staining (bottom). The figure is representative of two independent experiments. 
Figure 9 : Down regulation of ER by ER $\alpha 17 p$ analogs. MCF-7 cells were cultured during 6, 24 and 48 hours in the absence (control) or presence of ER $\alpha 17 p$, ER $\alpha 17 p A A$ or ER $\alpha 17 p G G$ all at $10 \mu \mathrm{M} . \mathrm{A}:\left[{ }^{3} \mathrm{H}\right] \mathrm{E}_{2}$ binding parameters $(\mathrm{Kd}, \mathrm{Bmax})$ were determined by whole cell binding assay and Scatchard plot analysis. The figure is representative of three experiments where $K d$ ranged from 0.08 to $0.33 \mathrm{nM}$. Bmax values (mean $\pm S D$ ) are given as percentage of control. B. ER level determination. Cells were incubated with $0.1 \mathrm{nM}$ of $\mathrm{E}_{2}$ or either 1 and $10 \mu \mathrm{M}$ of $\mathrm{ER} \alpha 17 \mathrm{p}, \mathrm{ER} \alpha 17 \mathrm{pAA}$ or ER $\alpha 17 p G G$. ER and actin levels were then assayed by Western blot analysis using F-10 and MAB1501R antibodies. Immunoblots are representative of three independent experiments. Densitometric analysis values (ratio of ER / actin ODs) are given and expressed as percentages of control. * OD not quantified.

Figure 10 : ERE-dependent transcription induced by ER $\alpha 17 p$ analogs. MVLN cells were incubated for 6,24 and 48 hours in the absence (control) or presence of $0.1 \mathrm{nM}$ of $\mathrm{E}_{2}$ or $\mathrm{ER} \alpha 17 \mathrm{p}, \mathrm{ER} \alpha 17 \mathrm{pAA}$ and $\mathrm{ER} \alpha 17 \mathrm{pGG}$ all at $10 \mu \mathrm{M}$. Luciferase activity was assayed in cellular extracts by luminometry and emitted light signals were expressed in arbitrary units (relative luciferase units, RLU) per mg protein. Data refer to the mean value \pm SD of three independent experiments with measurements performed in duplicate and are given as percentage of controls. All compounds induced a significant increase as compared to the corres ponding controls.

Figure 11 : Influence of ER $\alpha 17 p$ and ER $\alpha 17 p$ analogs on growth of breast cancer cell lines. ER-positive and ER-negative breast cancer cell lines were grown for 24,48 and 72 hours in the absence (control) and presence of $0.1 \mathrm{nM}$ of $E_{2}$ or of ER $\alpha 17 p, E R \alpha 17 p A A$ and ER $\alpha 17 p G G$ all at $10 \mu \mathrm{M}$. Cell growth was measured by 
crystal violet staining. Measurements were performed in sixplicate. Data refer to the mean value \pm SD of a representative experiment performed three times.

Figure 12 : Constitutive activity of an ER mutant deleted for ER $\alpha 17 p$ motif. Evsa-T cells were transiently transfected with ERwt or ER $\Delta \mathrm{ER} \alpha 17 \mathrm{p}$ in the presence of Vit-tk-Luc (ERE-mediated expression of firefly luciferase) and pRL-tk (basal expression of Renilla luciferase) reporter plasmids. Cells were then incubated for 24 hours in the absence (control) or presence of $0.1 \mathrm{nM}$ of $E_{2}$ or / and $10 \mu \mathrm{M} E R \alpha 17 p$. Luciferase activities were assayed in cellular extracts by luminometry and emitted light signals were normalized with respect to Renilla luciferase activity. Values are expressed as percentage of that obtained with ERwt-transfected cells (control). Data refer to mean values $( \pm S D)$ of at least four independent experiments. * and $\ddagger$ Significantly higher as compared to untreated ERwt-transfected cells. No significant difference was noted between $R L U$ values measured in $E R \Delta E R \alpha 17 p$-transfected cells. 


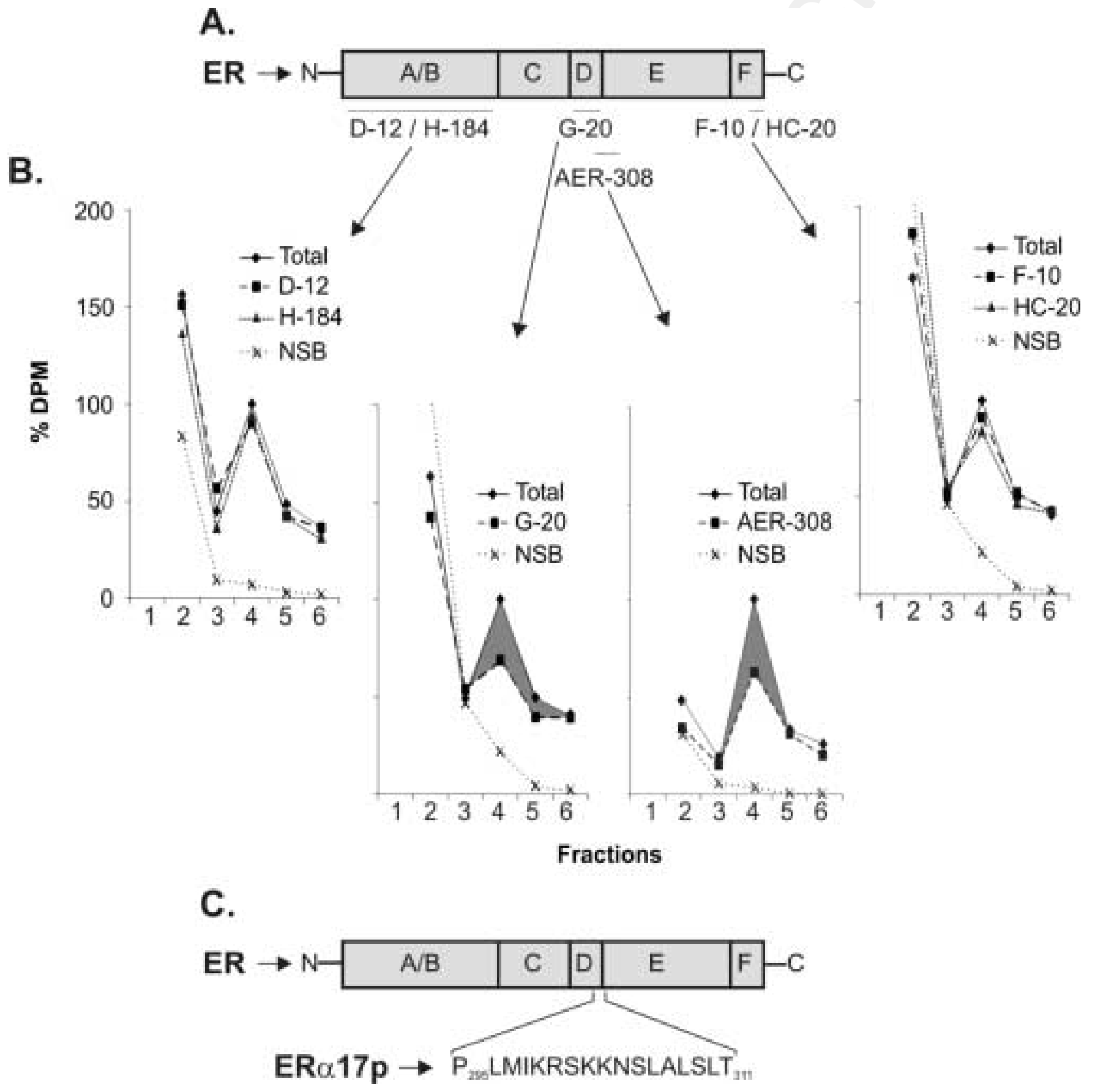




\section{ER $\rightarrow$}<smiles>[Co][Co]</smiles><smiles>[C]=[V]</smiles><smiles>O=C1C#CC(=O)O1</smiles><smiles>O=CC1CCCO1</smiles>
$0^{2}$ 
A.

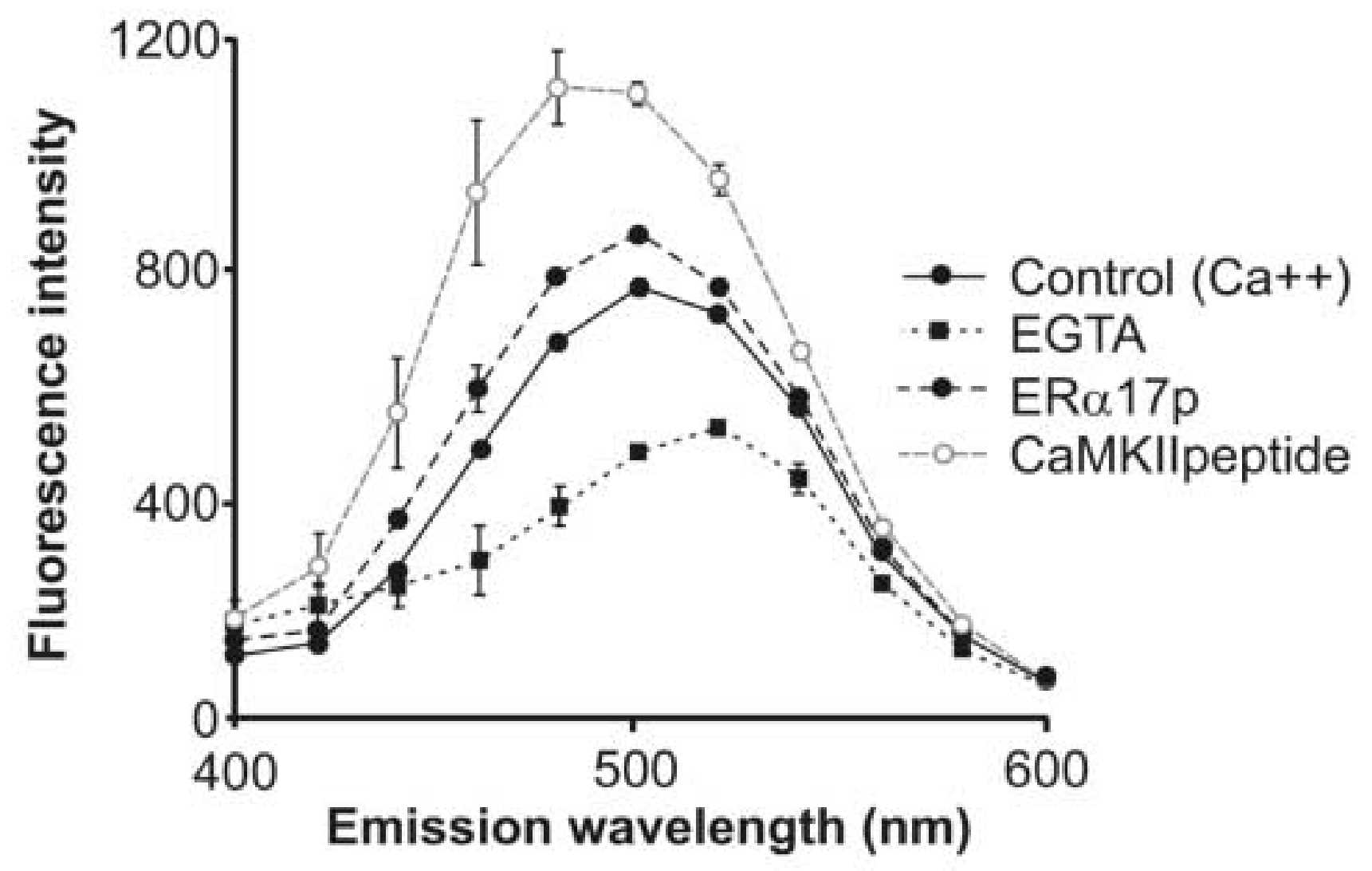

B.

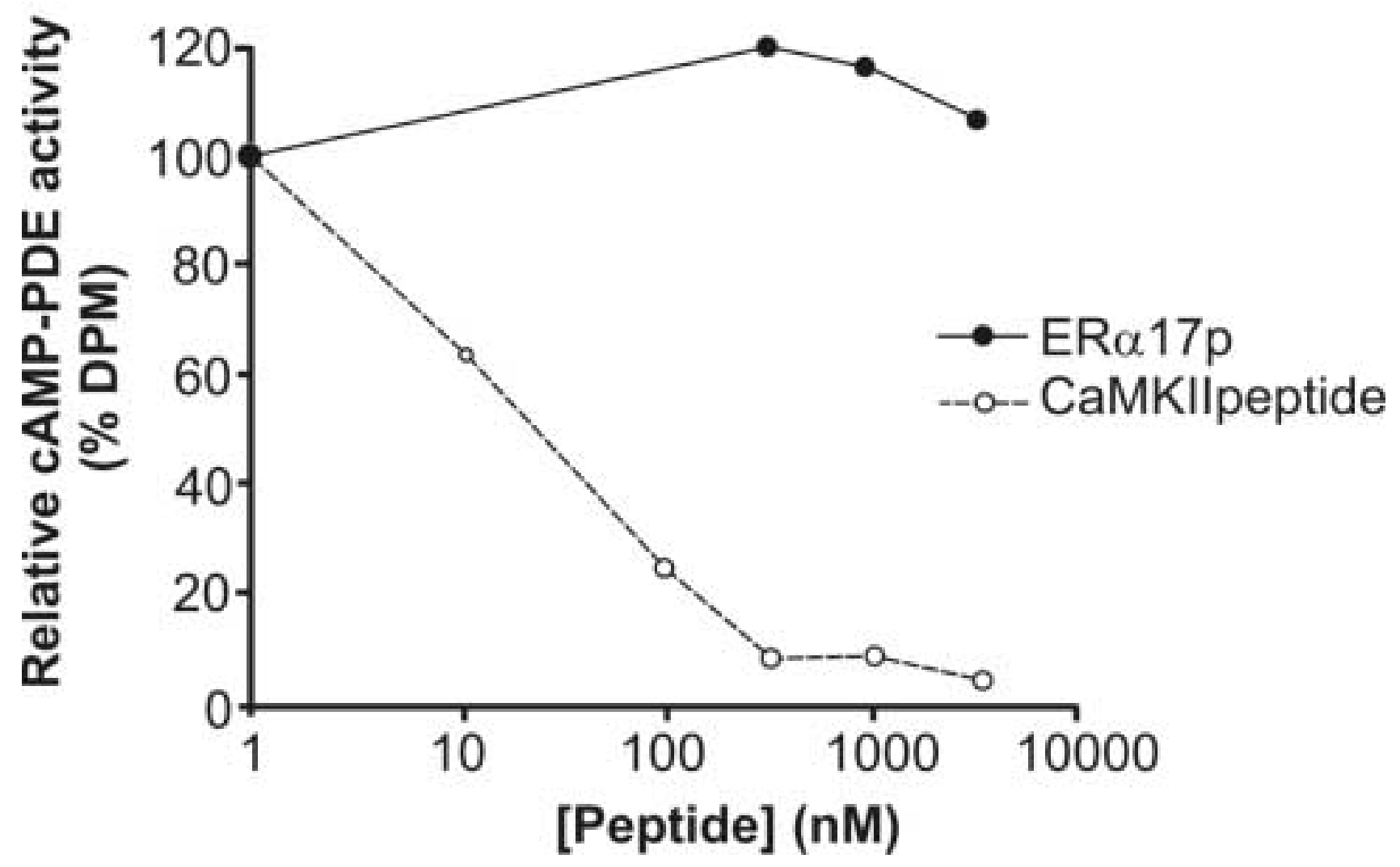




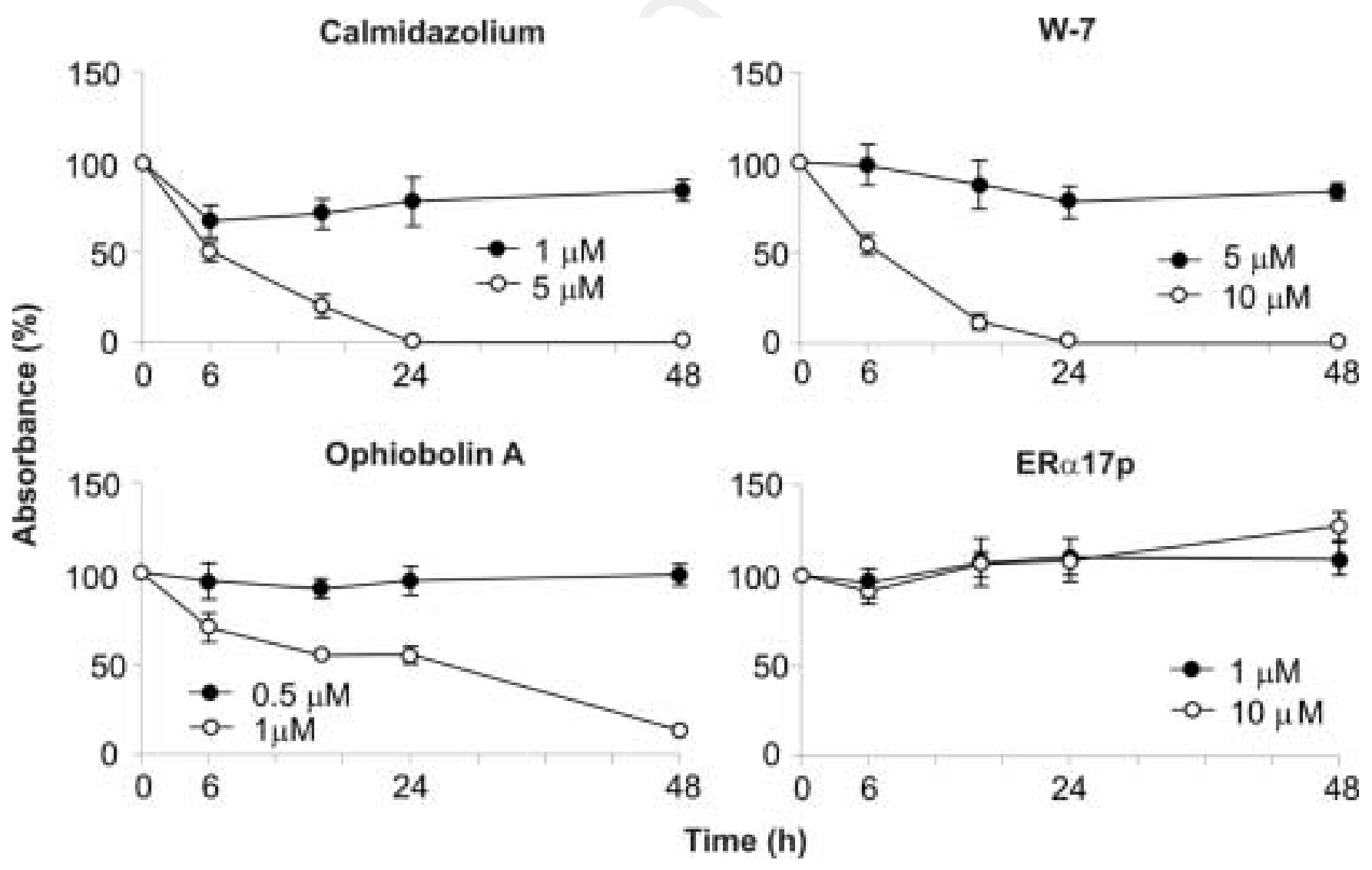




\section{ER $\rightarrow$}

$\mathrm{CaM} \rightarrow$

$\mathrm{CaM} / \mathrm{ER}$ (\% OD)

72

10453

42
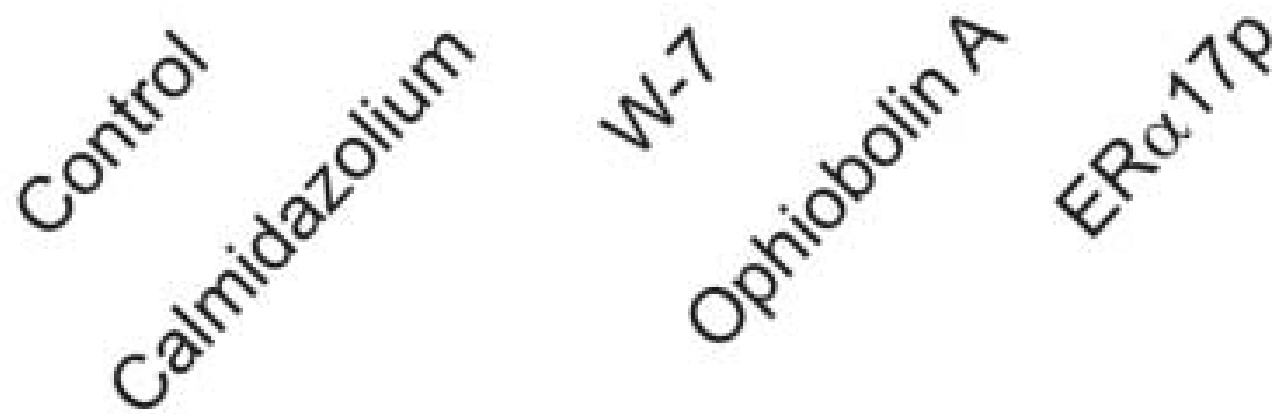

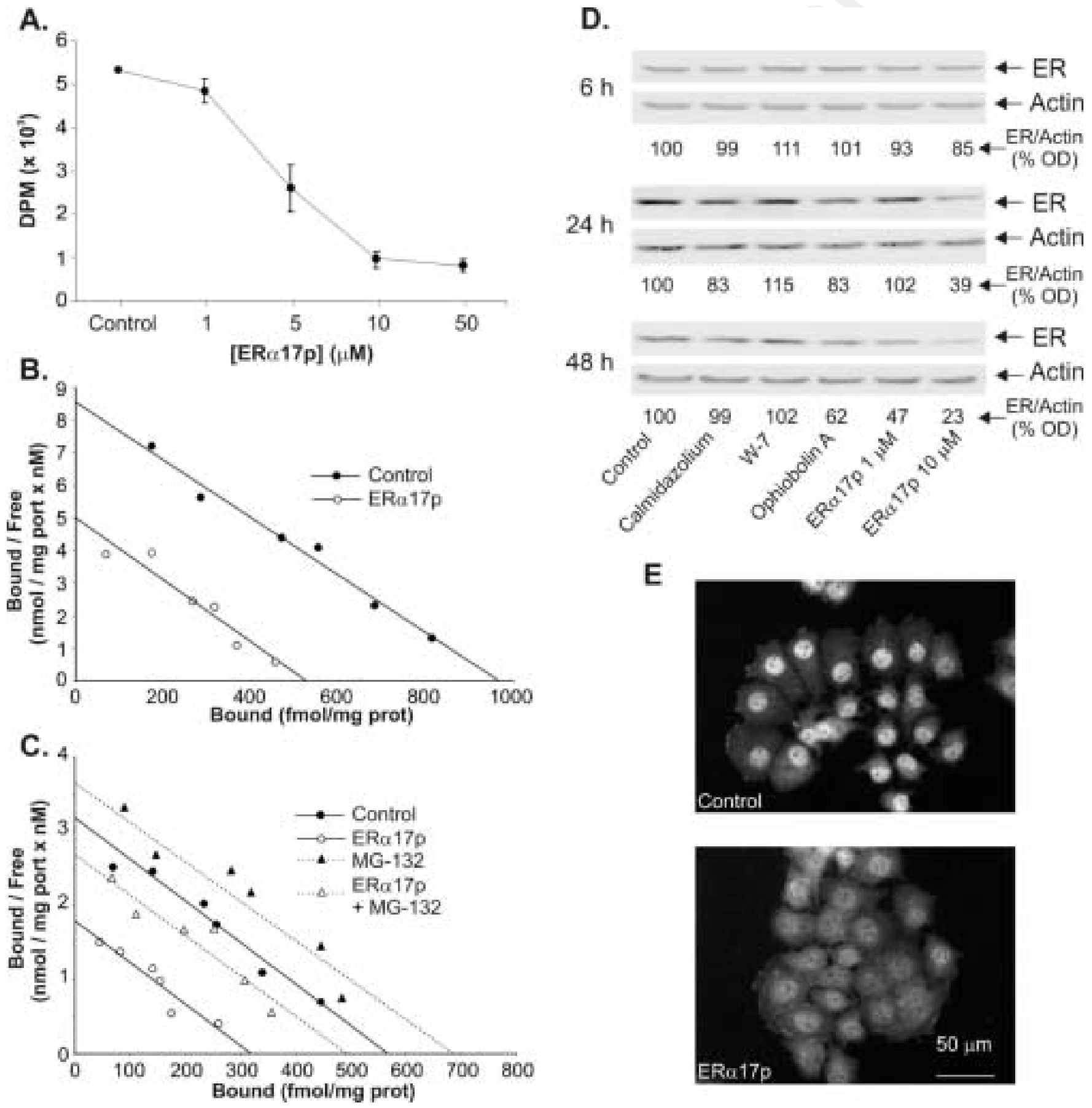


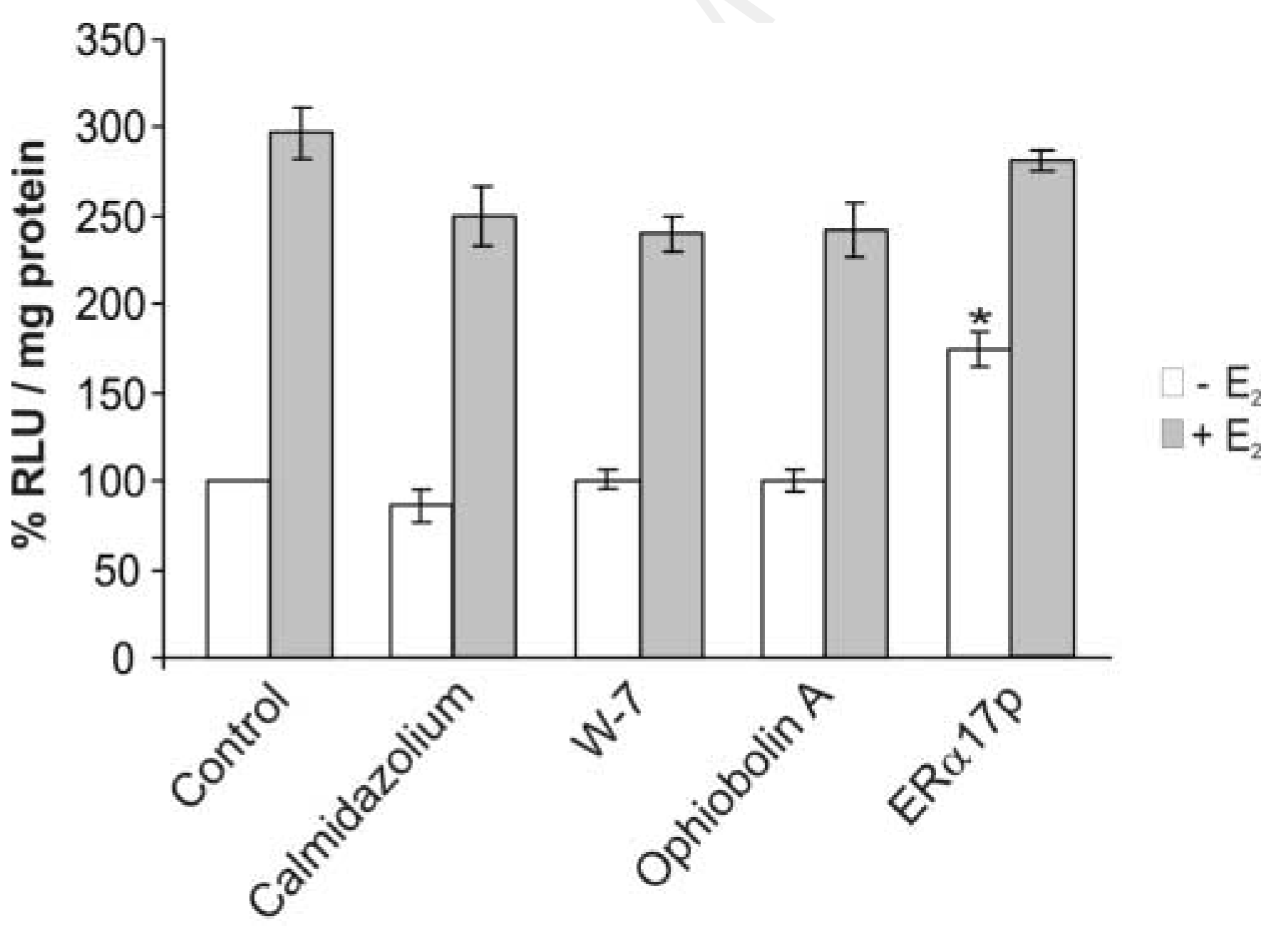


A.

Sepharose 4B CaM-Sepharose

\section{$E R \propto 17 p \rightarrow$}

$E R \alpha 17 p A A \rightarrow$

$E R \alpha 17 p G G \rightarrow$

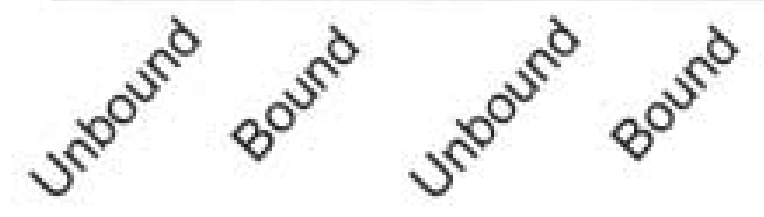

B.

CaM-Sepharose extracts

$\mathrm{ER} \rightarrow$

Peptides $\rightarrow$

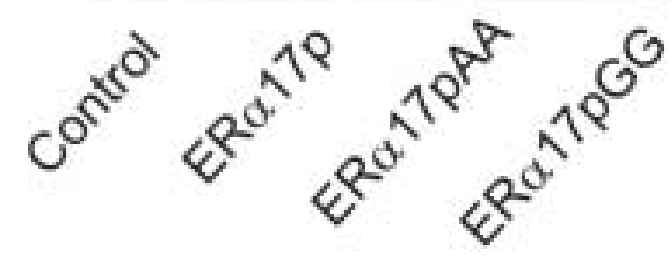



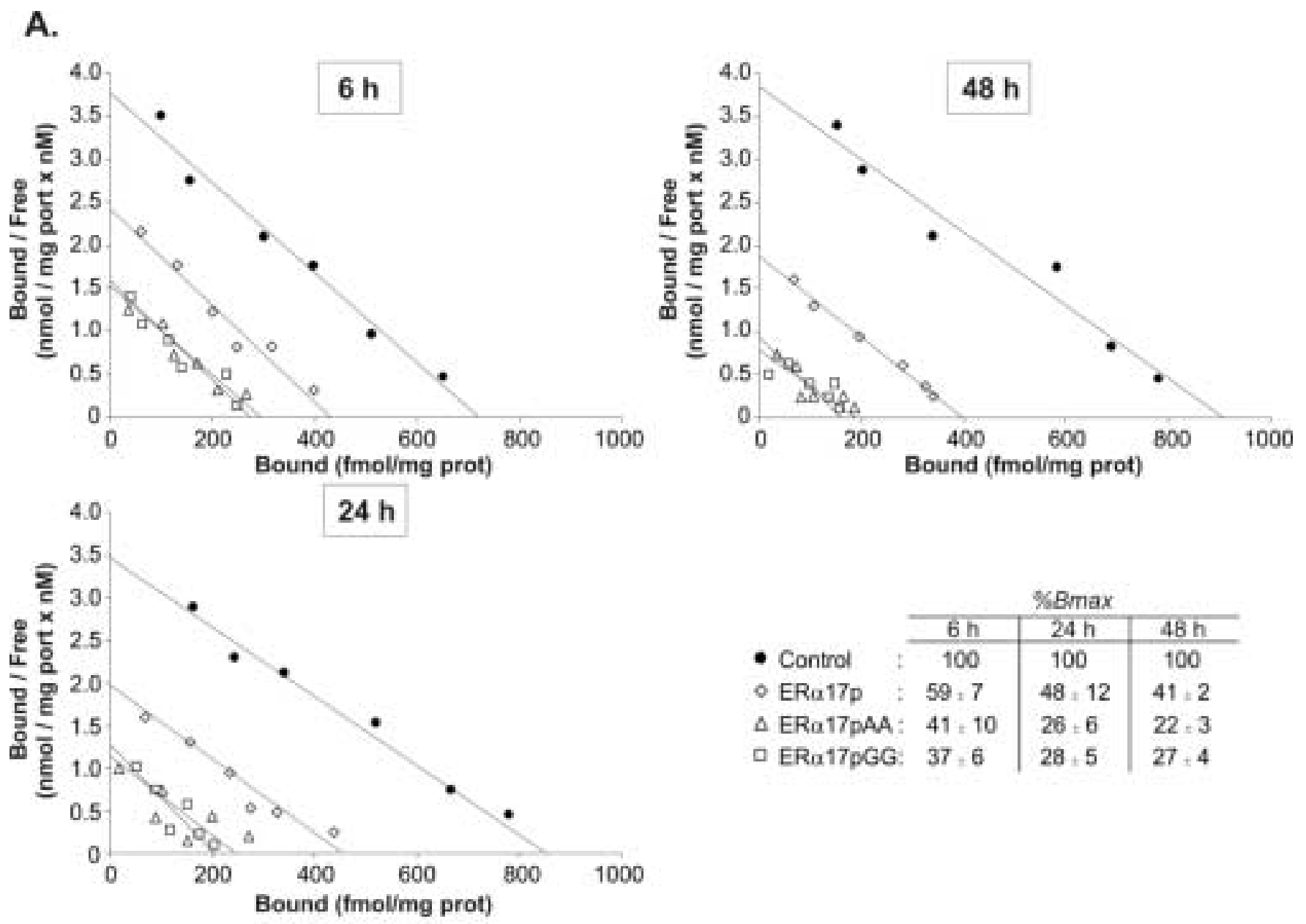

\begin{tabular}{|c|c|c|c|}
\hline & \multicolumn{3}{|c|}{ \%Bmax } \\
\hline & $6 \mathrm{~h}$ & $24 \mathrm{~h}$ & $4 \mathrm{Bh}$ \\
\hline Control & 100 & 100 & 100 \\
\hline ERa17p & $: 59.7$ & $48 \cdot 12$ & $41: 2$ \\
\hline ERo 17pAA & $: 41.10$ & $26 \div 6$ & $22 \cdot 3$ \\
\hline ERa17pGG & 2: 37.6 & 28,5 & $27+4$ \\
\hline
\end{tabular}

B.

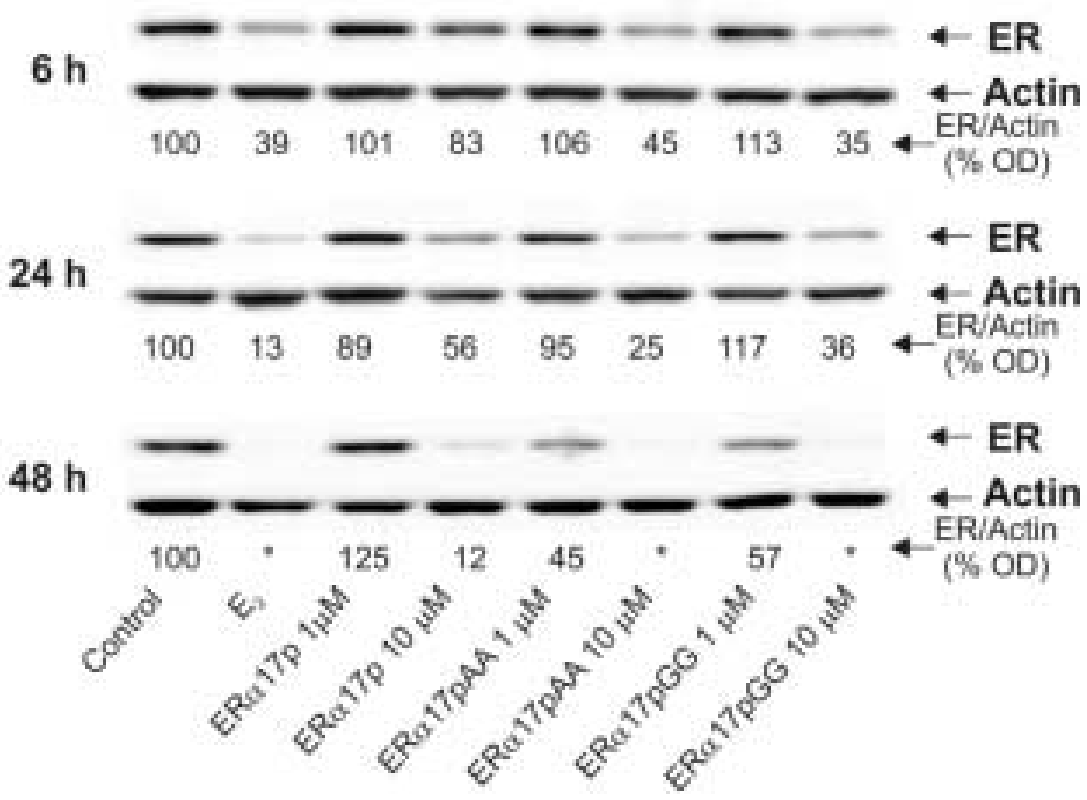




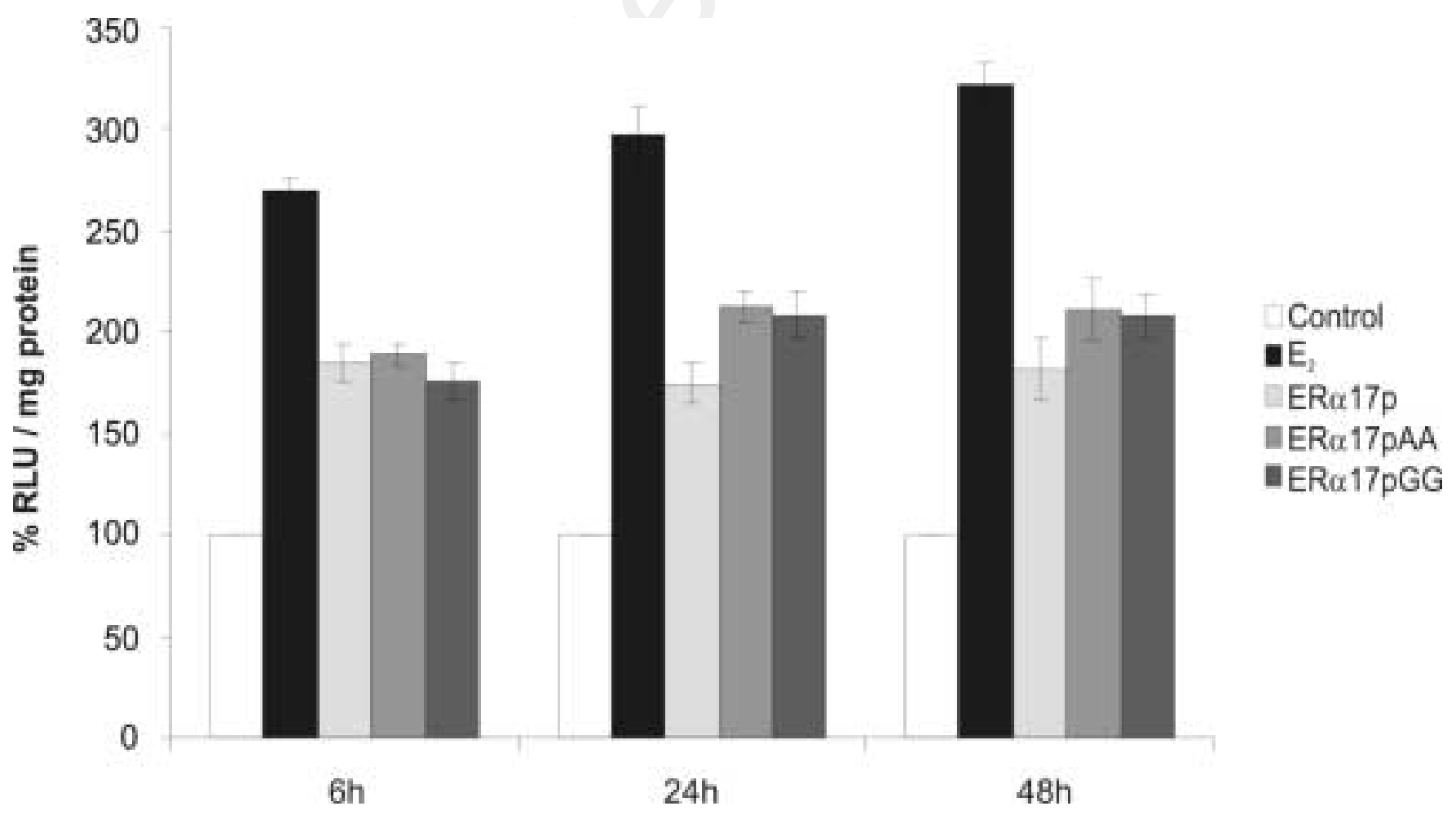

Page 53 of 55 


\section{ER +}
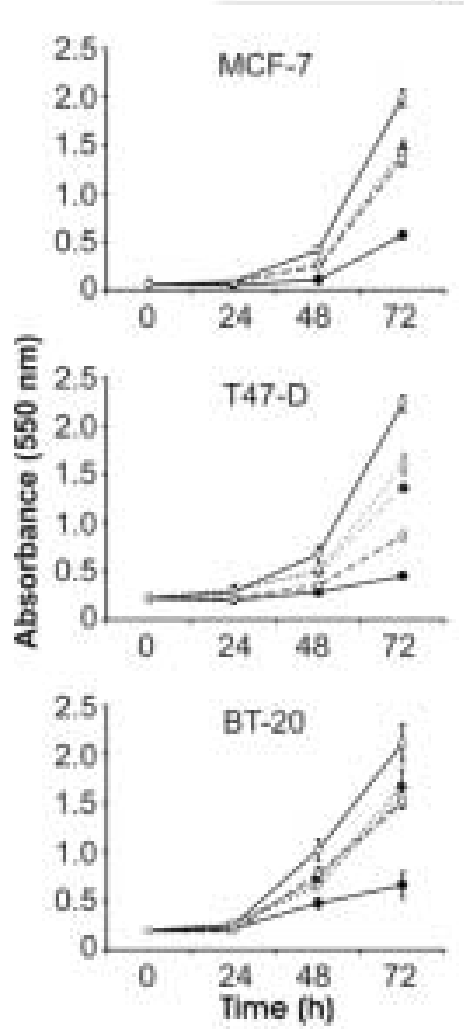

ER -
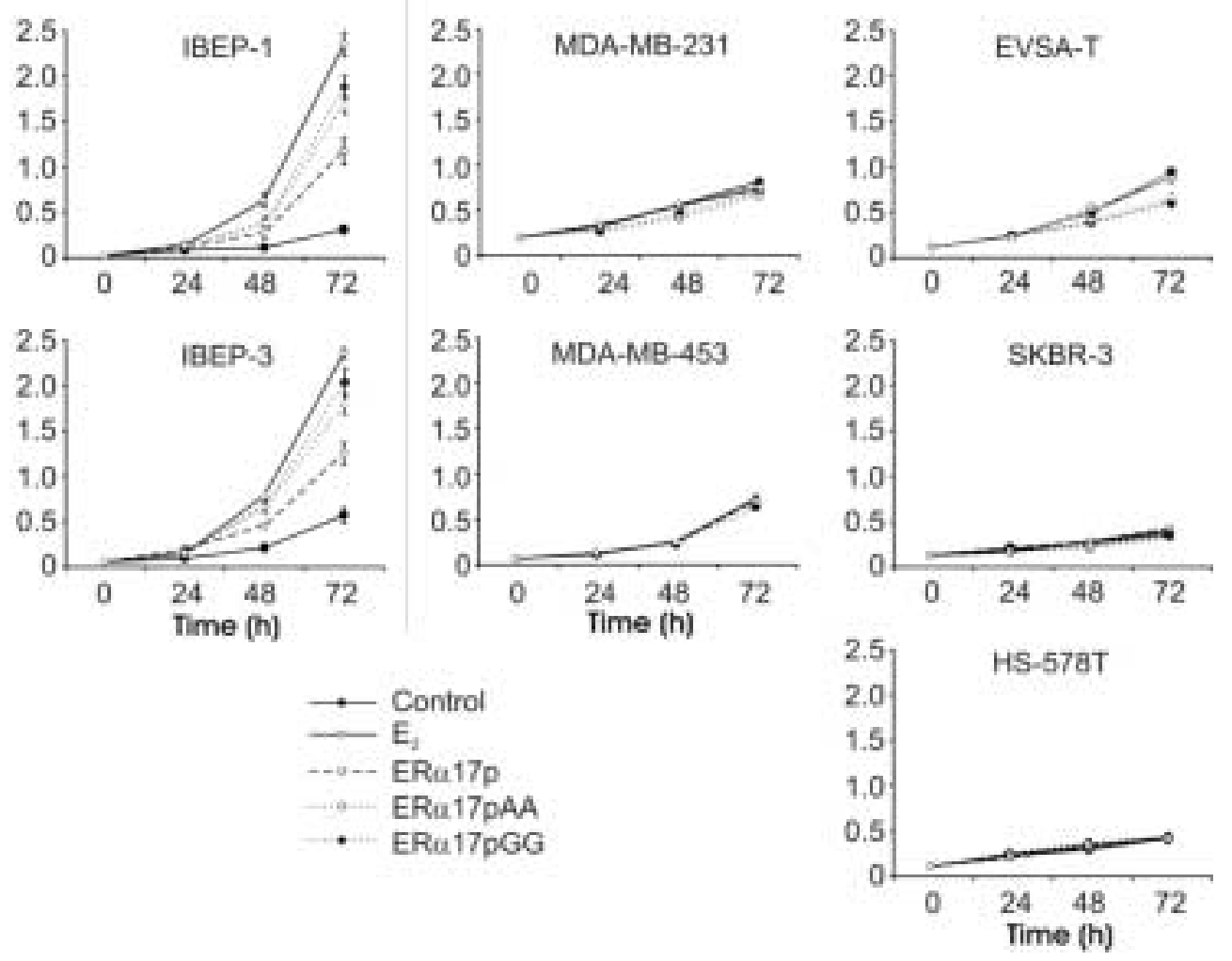


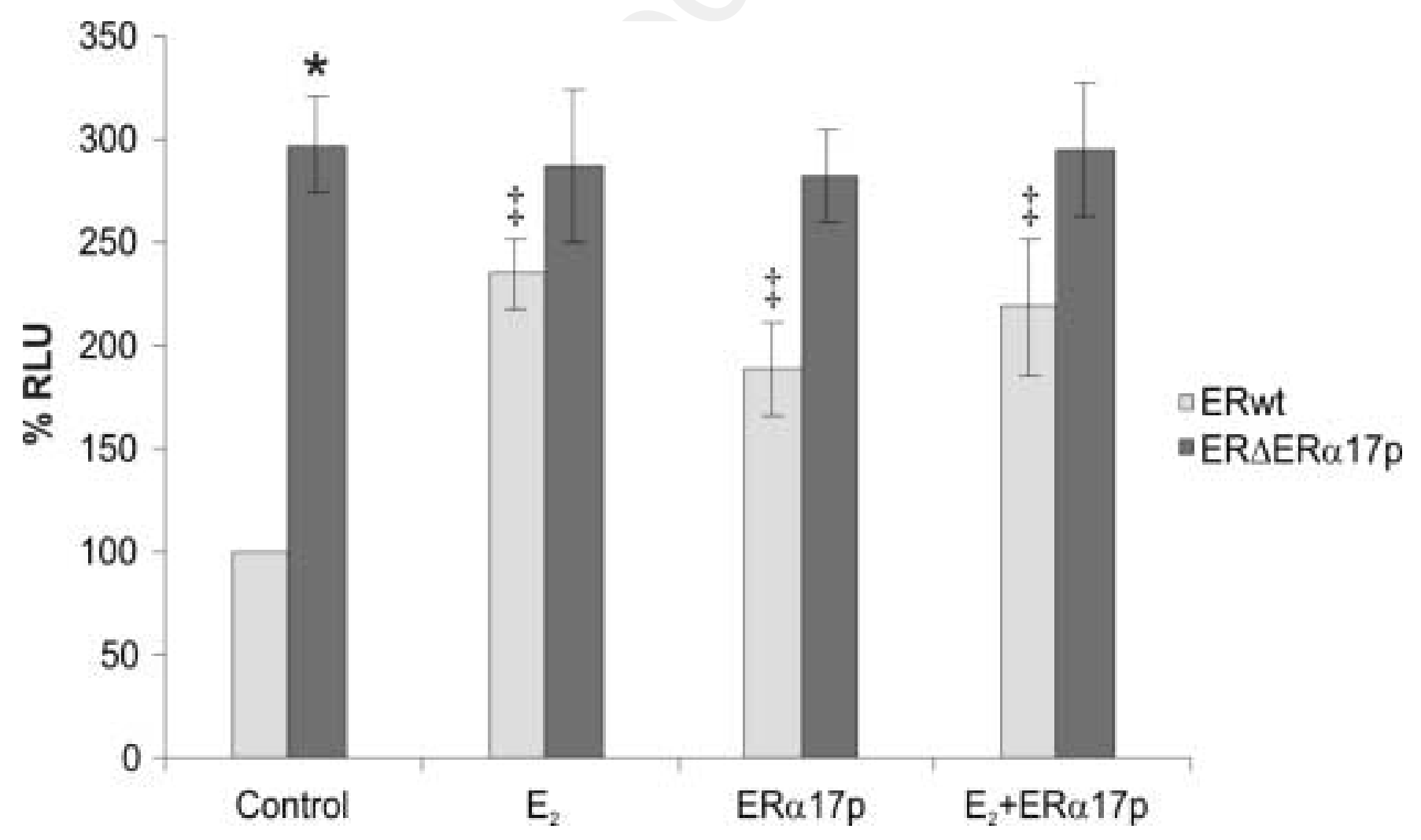

Page 55 of 55 